\title{
Benlik Saygısı ve E-Katılım İliş̧isi: Twitter Ekseninde Akademisyenlere Yönelik Bir Uygulama ${ }^{1}$
}

\author{
Relationship between Self-Esteem and E-Participation: A Research \\ about Academics on Twitter Platform \\ Şakir GÜLER*, Murat SEZGIN*** \\ • Geliş Tarihi: 27.07.2019 • Kabul Tarihi: 12.11.2019 • Çevrimiçi Yayın Tarihi: 12.11.2019
}

\begin{abstract}
Öz
Bu çalışmanın amacı akademisyenlerin benlik saygıları ve Twitter platformunda gerçekleştirmiş oldukları siyasal katılım davranışları arasındaki ilişkiyi ele almaktır. Bu doğrultuda araştırmanın çalışma evrenini Uşak Üniversitesi, Gümüşhane Üniversitesi ve Süleyman Demirel Üniversitesi akademisyenleri oluşturmaktadır. Çalışma evreni içinde yer alan kümelerin tümünün, evreni temsil olasılıklarının birbirinden bağımsız ve eşit olabilmesi için katılımcılar cinsiyet ve unvan kotaları dâhilinde tabakalı örnekleme usulüyle seçilmiştir. Araştırma sonunda ulaşılan bulgulara göre akademisyenlerin benlik saygıları ve e-katılım durumları arasında; "siyasal ifade", "siyasal tartışmalara katılma" ve "yerel yönetime katılma" alt boyutları arasında negatif yönde anlamlı ilişki tespit edilmiştir. Öte yandan katılımcıların hayalperest olma durumlarının artmasıyla siyasal ifadede bulunma, siyasal tartışmalara katılma ve yerel yönetime katılma puanlarının arttığı sonucuna ulaşılmıştır. Genel olarak Twitter temelli e-katılım davranışları düşük düzeyde seyreden akademisyenlerin yalnızca platform üzerinden politika ve hizmet takibinde bulundukları sonucuna varılmıştır. Araştırma sonuçları alanyazında yer alan eğitim faktörünün artmasıyla benlik saygısının artacağı tezi ile örtüşürken, eğitim faktörünün artması ile siyasal katılımın artacağı kanaati ile çelişmektedir.
\end{abstract}

Anahtar sözcükler: benlik saygısı, e-katılım, akademisyenler, Twitter

Atıf:

Güler, Ş. ve Sezgin, M. (2020). Benlik saygısı ve e-katılım ilişkisi: Twitter ekseninde akademisyenlere yönelik bir uygulama. Pamukkale Üniversitesi Eğitim Fakültesi Dergisi, 49, 413-438. doi: 10.9779/pauefd.597577

\footnotetext{
${ }^{1}$ Bu makale Şakir GÜLER'in "benlik saygısı ve Twitter'da siyasal katılım ilişkisini" konu alan doktora tezinden türetilmiştir.

* Dr. Öğrencisi, Uşak Üniversitesi, İletişim Bilimleri ABD. sakirguler@yandex.com. ORCID ID: 0000-0002-73656639.

** Doç. Dr., Uşak Üniversitesi, Halkla İlişkiler ve Reklamcılık Bölümü, murat.sezgin@usak.edu.tr. ORCID ID: 0000-0003-2200-3301.
} 


\begin{abstract}
The aim of this study is to investigate the relationship between academics' self-esteem and their political participation behaviors on Twitter. The study population of the research consists of academicians from Uşak University, Gümüşhane University, and Süleyman Demirel University. Participants were selected by stratified sampling within the gender and title quotas. According to the findings of the research, the self-esteem of academicians and their political participation status on Twitter, there is a negative correlation between "political expression", "participation in political discussions" and "participation in local government". On the other hand, it has been concluded that the participation of the academicians in political expression, their "participation in political discussions" and their "participation in the local government" have increased with the increase in their dreamer side. It was concluded that academics' e-participation behaviors on Twitter were low and they followed only policies and services via Twitter. The research findings support the thesis that self-esteem will increase with the increase in the education level in the literature and research findings contradict the opinion claiming that political participation will increase with the increase of the education level.
\end{abstract}

Keywords: self-esteem, e-participation, academician, Twitter

\title{
Cited:
}

Güler, Ş. \& Sezgin, M. (2020). Relationship between self-esteem and e-participation: A research about academics on Twitter platform. Pamukkale University Journal of Education, 49, 413-438. doi: 10.9779/pauefd.597577. 


\section{Giriş}

Bireyler dış dünyadaki insanlara, nesnelere ve olgulara yönelik belirli tutumlar geliştirmek suretiyle kanaat edinmektedirler. Kişinin kendisine yönelik geliştirdiği tutumlar ise benlik saygısı çerçevesinde ele alınmaktadır. Bu kapsamda insanların kendi benliklerini bir değerlendirmeye tabi tutma sonucunda benlik saygılarını betimlediği ifade edilebilir. Nitekim benlik saygısı kişinin varoluşsal haritadaki konumunu tayin eden benlik kavramı üzerinde temellenen bir yapıya sahiptir (Rosenberg, 1965, s. 5). Dolayısıyla insanoğlunun dâhil olduğu her ortam bireyin benliğinden doğal bir etkileşim uzamında kaçınılmaz suretle etkilenmektedir. Bilgi iletişim teknolojilerinin gelişimi ile ortaya çıkan sosyal platformlar da insanların dâhil olduğu yeni iletişim ortamları kapsamında yer almaktadır. Dolayısıyla bireylerin bu ortamlarda gerçekleştirdiği eylemler de kişilerin benliğinden bağımsız değildir. Öte yandan insanoğlunun dâhil olduğu her mecrada yöneten ve yönetilen kümeleri meydana gelmekte, yönetim erklerinin almış olduğu kararlar yönetilenleri her mecrada bağlamaktadır. Aynı şekilde yönetilenlerde her mecrada yönetim kararlarını etkileme potansiyeline sahiptirler. Yönetilenlerin yöneticileri etkileme çabası olarak tanımlanan siyasal katılım davranışı ise bilgi iletişim teknolojilerinin gelişmesiyle farklı biçimler kazanmış, e-katılım olarak adlandırılan sanal mecralarda siyasal katılımı konu alan yeni bir form ortaya çıkmıştır. Dolaysıyla söz konusu sanal ortamlar kamusal alanı temsil eden birer mecra haline gelmişlerdir. Bu kapsamda ilgili araştırma çerçevesinde akademisyenler üzerinden Twitter platformu dâhilinde siyasal katılımı ve benlik saygısı arasındaki ilişkiyi konu alan bir araştırma gerçekleştirilecektir.

Araştırmanın temel problemini; katılımclların benlik saygısı ile Twitter'da gerçekleştirdikleri siyasal katılım davranışları arasındaki iliş̧i (P) oluşturmaktadır. Öte yandan katılımcıların benlik saygısı (BS) düzeyleri (p1), Twitter'da siyasal katılım düzeyleri (p2), benlik saygısı bazında Twitter'da gerçekleştirilen e-katılım davranışları açısından farklılaşma durumları (p3) ve demografik faktörler bağlamında (bs-hayalperestlik-e-katılım) farklılaşma (p4) durumları araştırmanın alt problemlerini oluşturmaktadır. Çalışma sosyal medyada gerçekleştirilen siyasal katılım davranışlarını benlik saygısı ile ilişkilendirmesi yönüyle önem taşımaktadır. Dolayısıyla araştırmaya geçmeden önce benlik saygısı, siyasal katılım ve Twitter platformu gibi bileşenler detaylı bir biçimde ele alınarak ilgili araştırma deseni netleştirilecektir.

\section{İnsanın Varoluşsal Haritadaki Konumu Benlik}

Modern toplum düzeni içinde bireyler yaşamlarını idame ettirebilmek ve kendilerine addedilen rolleri gerçekleştirebilmek için her şeyden önce sağlıklı kişilik gelişimine ihtiyaç duymaktadırlar (Can, 1990, s. 1). Sağlıklı kişilik gelişimi, bireyin kendini ben olarak algılamasına ve diğer toplum üyelerinin mesafe alanlarını iyi idrak edebilmesine yardımcı olmaktadır (Fromm, 1955, s. 59). Bu noktada "ben" bilincinin canlılar dünyasında yalnızca insana özgü bir idrak düzeyi olduğu, insanların kendi dışındaki varlıkları öteki olarak nitelendirdiği dile getirilmektedir (Fromm, 1955). İlgili bağlamdan hareketle benlik kavramı kişinin öznel tahlille kendisini yorumlaması olarak ele alınmaktadır (Güney, 2009, s. 210). Arapçada "nefs", İngilizcede "self" sözcükleriyle tanımlanan benlik, literatürde manası tam olarak netleşmeyen ve üzerinde birden fazla tanım bulunan bir kavram olarak karşımıza çıkmaktadır. İnsanın varoluşsal haritadaki konumunu tayin eden benliğin bu denli önemli bir merkezde yer almasına karşılık, üzerinde anlaşılmış ortak bir tanımının olmaması kavramın 
boyutlarının oldukça geniş olmasıyla ve birden fazla uzamı alakadar etmesiyle ilgilidir. Kavram daha yakından ele alındığında birden fazla disiplinin farklı biçimlerde ona anlam yüklediği görülmekte, sosyoloji, felsefe, antropoloji ve psikolojideki benlik kavramlarının birbiri ile örtüşmediği göze çarpmaktadır (Yalçın, 2011, s. 28). Bu durumdan hareketle çalışma kapsamında ilerleyen bölümlerde kullanılacak olan benlik ve benlik saygısı kavramlarının psikoloji disiplinindeki ele alınış biçimleriyle kullanılmış olduğunu belirtmek yerinde olacaktır.

Psikoloji disiplini çerçevesinde benlik kavramı ilk olarak William James (1983) tarafindan "Psikolojinin Prensipleri" adlı eserde ele alınmaktadır. James benlik kavramını "bilen benlik (self as knower)" ve "bilinen benlik (self as known)" ayrımıyla netleştirerek bilimsel araştırmalarda bilinen benliğin üzerinde durulabileceğini söylemektedir. Bu kapsamda psikoloji disiplininde benlik, bireyin kendini ne olarak gördüğü, ne olmak istediği ve çevresince nasıl tanındığg ile ilgili bir tasvire karşılık gelmektedir. Söz konusu disiplin içerisinde benlik kavramına Carl Gustav Jung gibi kimi öncüler kişiliğin bilinçli bir parçası olarak yaklaşmaktayken, Erikson gibi kimi isimler ise sağlıklı kişilik gelişimi için bir oto kontrol mekanizması olarak yaklaşmaktadır (Bakırcıoğlu, 2012, s. 42). Türk Dil Kurumu ise benlik kavramını bireyin öz varlığı, şahsiyeti ve kendiliği olarak tanımlamakta, bireyi kendisi yapan tüm olguları bu dairede ele almaktadır (Tdk, 2018a). İnsanların zihinlerinde temsil ettikleri bir ben nitelendirmesiyle de benlik kavramının somutlaştırılmaya çalışıldığına rastlanmaktadır (Aydın, 2005, s. 11). Kişinin kendine yönelik algıları, deneyimleri, geçmişte yaşamış olduğu tecrübeler ve geleceğe yönelik öngördügü hedefler, "bana göre ben kimim" sorusuyla benlik kavramını gün yüzüne çıkarmaktadır (Aydın, 2005, s.11-12). Diğer yandan tarihsel süreç içerisinde benlik kavramı bir tahlile tabi tutulduğunda, yine aynı şekilde insanların ben olma bilinci ve öteki olarak addetme içgüdülerinin ön plana çıktığı göze çarpmaktadır. Örneğin batı tarihinde benlik kavramı bireylerin kendilerini bağlı bulundukları derebeyliklerden ve klanlardan ayrı biçimde öznel olarak tanımlayabilmesi neticesinde günümüzdeki anlamına everilmeye başlamıştır. Geçmiş dönemlerde kullanılan biçimiyle günümüzde kullanılan ben kelimesi batılılar için (Kıta Avrupası) aynı manayı taşımamakta, eski zamanlardaki ben kelimesi ile batılılar bağlı bulundukları klanın tümünü nitelendiren "biz" zamirini kast etmektelerdi. Söz konusu feodal sitemlerin yıkılmasıyla birlikte bahsi geçen "ben" manası sarsıntıya uğrayarak "ben kimim" sorusu yeni bir kimlik arayışı içinde olan insanların geneli tarafindan sıkça sorulmaya başlanmıştır. Bu soru aynı zamanda ünlü düşünür Descartes tarafından da dile getirilen "var olduğumu nasıl bilebilirim?", "ben kimim" sorusudur. Bilindiği üzere soruya verilen yanıt "düşünme" eyleminin gerçekleştiği ölçüde bir varlıktan ve benlikten emin olunabileceğiyle ilgilidir (Fromm, 1955, s. 60). Dolayısıyla çeşitli disiplinlerin benlik kavramını ele alış biçimlerinde farklılıklar olmakla birlikte her biri benlik kavramının netleştirilmesine katkı sağlamaktadır. Öte yandan insan doğasının ayrılmaz bir parçası olması nedeniyle benlik, kişinin dâhil olduğu birçok alanda karar alma süreçlerini etkilemekte dolayısıyla birey kendi benliği doğrultusunda yönelimler sergilemektedir (Erikson, 1993). Siyasal katılımın gerçekleştirildiği alanlarda bu kapsam dâhilindedir. Bu noktada benlik saygısı, kişinin vermiş olduğu kararlardan ve dâhil olduğu ortamlardan aldığı geri dönüşler nihayetinde birey için oldukça önemli bir tablo ortaya koymaktadır. İlgili bağlama geçmeden önce benlik saygısı kavramına değinmek konunun daha iyi idrak edilmesine yardımcı olacaktır. 


\section{Benlik Saygısı}

Doğası gereği insanlar dış çevredeki, nesnelere, eylemlere ve diğer bireylere yönelik belirli tutum ve kanaatler geliştirmektedir. Bu tutum ve kanaatler doğrultusunda dış çevre anlam kazanmaktadır. Söz konusu değerlendirmeye birey kendi şahsını tabi tuttuğunda oluşan kanaatler ise bireyin benlik saygısını oluşturmaktadır. Diğer bir ifadeyle benlik saygısı bireyin kendi benliğine yönelik geliştirdiği tutumlardan meydana gelmektedir (Kaya ve Saçkes, 2004, s. 1). Rosenberg (1965) bireyin kendine yönelik geliştirdiği olumlu ve olumsuz kanaatlerin tümünün benlik saygısı dairesinde yer aldığının altını çizmektedir. Kişisel memnuniyet, haysiyet, öz-konumlandırma, öz-sayg1 gibi değerlerin tümü benlik saygısı olarak adlandırılmaktadır. Çocukluk dönemlerinden itibaren şekillenen benlik saygısı üzerinde kişisel olarak kurulan etkileşimler önemli yer tutmaktadır (Doğan ve Totan, 2099, s. 237). James (1983) benlik saygısını başarının isteklere bölünmüş hali olarak formüle etmektedir. Formülden hareketle kişinin başarılı olmayı arzu ettiği alanlarda ulaştı̆̆ sonuç neticesinde benlik saygısının artacağı ya da düşeceği sonucuna ulaşılmaktadır. Diğer bir ifadeyle benlik saygısı ile önem atfedilen alanlar arasında güçlü bir bağ söz konusudur. Bu kapsamda başarılı olmak istediği alanlarda hedefine ulaşmış bir bireyin kendine olan inancı ispatlanmakta ve daha özgüvenli bir yapıya kavuştuğu varsayılmaktadır (Tatlı, 2012, s. 15).

Benlik kavramında olduğu gibi benlik saygısında da karmaşık bir yapı söz konusudur. Nitekim kendi dışındakileri öteki olarak isimlendiren birey öz benliğini daha üstün olarak görmekteyken, kendi iç dünyasında yaptığı muhakeme neticesinde kendine yönelik de olumsuz tutumlar geliştirebilmektedir. Bu nedenle çeşitli çalışmalarda benlik saygısı düşük kümelere daha fazla hassasiyet gösterilerek benlik saygısı üzerinde olumsuz etki eden faktörler ortaya koyulmaya çalışılmaktadır (Donnellann, Trzesniewski, Robins, Moffitt ve Caspi, 2005, s. 329). Dolayısıyla insanın doğasını ilgilendiren bir konu olması hasebiyle benlik saygısı kavramı üzerine gerçekleştirilen çalışmalar oldukça geniş bir yelpazeye uzanmaktadır.

İlk olarak James (1983) tarafından ele alınan kavram üzerine 2006'lı yıllara gelinceye dek 23.215'ten fazla akademik çalışma gerçekleştirilmiş olup (Mruk, 2006, s. 1), bu rakam günümüze dek sürekli güncellenerek artmıştır. Gerçekleştirilen çalışmaların benlik saygısını çeşitli değişkenlerle ilişkilendirdiği ve kavramın disiplinler arası birçok alanda ele alındığı görülmektedir. Örneğin üniversite öğrencileri üzerinde gerçekleştirilen bir araştırmada; benlik saygısı ve şüphe durumu açısından katılımcıların siyasal reklamlara yönelik yaklaşımları ele alınmış olup siyasal reklama maruz kalan seçmenlerin psikografik durumlarının anlaşılmasının önemli olduğu vurgulanmaktadır (Tatl1, 2012). Öte yandan benlik saygis1, narsizm ve "demokratik bağlamda karşıt görüştekilere saygı duyma" durumlarını konu alan bir diğer çalışmada ise değişkenler arasındaki anlamlı ilişkinin örneklemin seçildiği ülkelere (ABD \& Polonya) göre değiştiği belirtilmektedir (Marchlewska, Castellanos, Lewczuk, Kofta, Cichocka, 2019, s. 11). Disiplinler arası bir diğer çalışmada ise siber zorbalık mağdurlarının durumları, benlik saygısı, empati ve yalnızlık gibi olgular üzerinden ele alınarak, benlik saygısı ve siber zorbalık mağduriyeti arasında negatif yönde anlamlı ilişki olduğu ortaya koyulmaktadır (Brewer, Kerslake, 2015, s. 257-258). Bahsedilen örneklerde de görüleceği üzere benlik saygısı, farklı alanlardaki birden fazla değişkenle ilişki içerisindedir. Bu çalışma kapsamında ise kavram, siyasal katılım davranışı ile ilişkilendirileceğinden, araştırma deseni doğrultusunda ekatılım ve siyasal katılım gibi kavramlara yakından bakmak gerekmektedir. 


\section{Siyasal Katılım Davranışı ve E-Katılım Çehresi}

Siyasal katılım faaliyeti literatürde farklı biçimlerde ele alınan bir konu olarak karşımıza çıkmaktadır. Bu nedenle tanımlamaya geçmeden önce kavramı oluşturan "siyaset" ve "katılma" olgularına değinmek gerekmektedir. Siyaset kavramı iki ayrı bakış açısı ile alan yazında tanımlanmaktadır. Bu bakış açılarından ilki, siyasetin devlet bilimi olduğu şeklinde bir tablo ortaya koymakta iken diğer bakış açısı siyaseti erk bilimi olduğunu iddia etmektedir (Eroğul, 1991, s. 13). Katılım kavramı ise Türk Dil Kurumunda iştirak etme, dâhil olma anlamlarıyla yer almaktadır (Tdk, 2019a). Bu bağlamda siyasal katılım kavramı alan yazında yer alan tanımların ortak paydasından hareketle; yöneticilerin almış olduğu kararlara yönetilenlerin katılımı ve etkileme çabası olarak ifade edilmektedir (Verba and Nie, 1972; Milbrath and Goel 1977; Conge, 1988, s. 242; Parry, Moyser, Day, 1992, s. 16; Brady, 1999, s. 738). Söz konusu katılım faaliyetini seçimlerde oy kullanmak eyleminden ibaret görmek nitekim eksik kalmaktadır. Katılma faaliyeti olağan bir meraktan güçlü ve aktif davranışlara varıncaya dek geniş bir dairede gerçekleştirilen çabaların tümüdür. Katılma eyleminin toplumsal yapı bünyesinde meydana geldiği göz önüne alındığında kamuyu oluşturan tüm katmanların bu faaliyete aktif olarak dâhil olması beklenilemez. Toplumsal yapı içinde yer alan bireylerin bir kısmı siyasete karşı ilgisiz olabildiği gibi diğer bir kısmı da oldukça ilgili davranabilmektedir (Kapani, 2009, s. 144).

Katılım faaliyeti demokratik sistemlerin yönetim ilkeleri arasında yer almakta olup demokrasiyi devam ettirmek için asgari koşul ve etkili bir araç olarak ön plana çıkmaktadır (Van Deth, 2001, s. 2-3). Diğer yandan siyasal sistemin nasıl bir doğrultuda inşa edildiği fark etmeksizin yönetim erkleri kendi otoritelerini tayin edebilmek ve mevcut sistemi devam ettirebilmek adına katılma faaliyetine olanak tanıyan mekanizmalar geliştirmek durumundadirlar (Uysal, 1984, s. 35).

Demokrasi kavramı faaliyet gösterdiği alan itibariyle öz olarak "siyasal katılma" kavramı ile bütünleşmiş bir yapıdadır. Siyasal katılımın olmadığı bir demokratik sistem hayal edilemediği gibi katılma davranışı yalnızca demokratik sistemlere özgü bir faaliyet de değildir. Demokratik sistemlerde yurttaşların kendilerini ve toplumu ilgilendiren konularda alınan kararları etkilemek maksadıyla muhakkak katılımda bulunmaları beklenilmektedir. Demokratik olmayan totaliler rejimlerde ve diğer benzer sistemlerde ise katılım faaliyeti daha çok yönetim erkinin çizdiği sınırlar çerçevesinde bir şekle bürünmektedir. Bu doğrultuda demokratik sistemlerde katılma faaliyeti her şeyden önce bir yurttaşl1k hakkı olarak değerlendirilmekte olup, sistemin devamlılı̆̆ 1 ve özü bu davranışın üzerine kurulmaktadır (Çukurçayır, 2006, s. 2627).

Dolayısıyla siyasal katılım faaliyeti günümüzde daha çok devlet yönetimine katılma şeklinde değerlendirilebilir (Eroğul, 1991, s. 12-14). Öte yandan günümüzde gerçekleştirilen ve kabul gören siyasal katılım faaliyetleri batı toplumlarında yaşanan sanayi ve siyaset devrimleri nihayetinde şekillenmiştir. Dolayısıyla batıdaki siyasal mekanizmaları idealize ederek transfer etmek isteyen toplumlar, ilgili sosyal süreçlere maruz kalmadan bu kavramları devşirmektedirler (Çukurçayır, 2006, s. 40). Bu nedenle katılım faaliyeti toplumdan topluma uygulamada farklı1ık gösterebilmektedir. Öte yandan farklı biçim ve formlara rağmen ancak öz olarak gönüllülük esasına dayanan meşru katılım eylemlerinin demokratik sistemle bütünleştiğini belirtmek gerekmektedir (McClosky'dan akt. Korkmaz, 2005, s.26). Nitekim siyasal katılımın biçim ve formlarına dair çalışmalar geniş bir yelpazeye uzanmakta ve yeni 
katılım biçimlerine dair tartışmalar devam etmektedir (Ekman ve Amna, 2012, s. 284-286). Gönüllülük esasına tabi siyasal katılım biçimlerinin netleştirilmesi ve gelenekselden e-katılım formuna geçişin tasvir edilmesi adına ilgili biçimlere değinmek yerinde olacaktır.

\section{Siyasal Katılımın Biçim ve Düzeyleri}

Katılma faaliyeti bireysel, toplumsal ve belirli örgütlenmeler çatısı altında gerçekleştirilebilmektedir (Eroğul, 1991, s. 179). Katılmanın nasıl gerçekleştirileceğine dair formlar ise çeşitli bağlamlarda birçok kategoride ifade edilegelmiştir. Bu bağlamda Chong Lim Kim (1974, s. 96-99) tarafından gerçekleştirilen siyasal katılım biçimleri şu şekildedir;

- Oy verme davranışı aracılığı ile oylamaya katılım,

- Çevresel ve milli problemleri konu edinen politik tartışmalara katılım,

- Siyasal kampanya süreçlerinde bir kampanyanın ya da siyasi temsilcinin desteklenmesi ile ilgili olarak politik kampanya süreçlerine katılım,

- Politik ya da sosyal örgütlenmeler çatısı altında yer alarak örgütsel faaliyetlere katılım,

- Vatandaşların belirli siyasal veya toplumsal konularda devlet temsilcileri ile iletişime geçmek amaciyla ilgili makama katılımı.

En sık tasnif edilme usullerine göre katılma biçimleri ele alındığında ise; olağan siyasal katılım ve olağan dışı siyasal katılım biçemlerinin ön plana çıktığ görülmektedir. Olağan siyasal katılım faaliyetleri altında yasal zemine uygun gerçekleştirilen siyasal katılım eylemleri yer almaktayken olağan dışı katılma biçimleri ise kurulu düzenin karşısında geliştirilen, kimi zaman fiziksel müdahaleleri içerebilen eylemler söz konusudur (Almond, 1974, s. 59; Çukurçayır, 2006, s.70).

Öte yandan Milbraith'e göre katılma davranışı, aktif veya pasif biçimde, kamuoyuna açık yâda kapalı olarak, gönüllü ya da zorlamaya tabi, sözlü yahut sözsüz türde, bireysel ya da kolektif bağlamlarda gerçekleştirilebilmektedir (Dilber, 2011, s. 10).

Katılma faaliyetleri zorluk ve kolaylık durumuna göre de bir ayrıma tabi tutarak tasnif edilmektedir. Bu çerçevede kolay faaliyetler "izleyici/seyirci faaliyetleri”, orta düzey zorluktaki katılım faaliyetleri "geçiş eylemleri", zor düzeydeki faaliyetleri ise "oyuncu (gladyatör) faaliyetleri” olarak tanımlamaktadır. Siyasal yaşamla ilgili eylemlerin yoğunluğu esas alınarak gerçekleştirilen bu ayrımda fazla bir çaba gerektirmeyen; oy verme, parti rozeti taşıma ve diğer vatandaşların siyasi düşüncelerini etkilemeye yönelik davranışlar, izleyici faaliyetleri kapsamında değerlendirilmektedir. Parti ve benzeri siyasal oluşumlara aktarılan para yardımları, bürokrat ve politik simalarla gerçekleştirilen düzenli ziyaretler, miting ve özel toplantılarda yer alma gibi daha yoğun eylemler ise geçiş faaliyetleri kategorisinde yer almaktadır. Öte yandan aktif olarak bir siyasi partinin adayı olma ve politik camiada herhangi bir siyasal oluşum dairesinde yoğun çaba gerektiren eylemler ise gladyatör eylemler olarak değerlendirilmektedir (Kalaycığlu, 1983, s. 11). Bu çerçevede katılma davranışına yönelik olarak Dahl, ilgi, önemseme, bilgi ve eylem olmak üzere dört farklı boyuttan söz etmektedir. Politik konuları izlemeye yönelik davranışlar "ilgi" boyutunu, olaylara atfedilen önem durumu "önemseme" boyutunu, söz konusu olaylara yönelik verilere sahip olma ise "bilgi" boyutunu oluşturmaktadır. 
Siyasal kararları etkilemeye yönelik faaliyetler ise "eylem" boyutu olarak değerlendirilmektedir (Kışlalı, 2006, s. 221).

Katılma faaliyetlerine dair biçim ve esaslar bu kadarla sınırlı olmayıp çağın getirdiği yenilikler ve siyasal sistemler referans alınarak yeni uzamlarda tartışılmaya devam etmektedir (Van Deth, 2001; Li ve Marsh, 2008; Ekman ve Amna, 2012). İlgili tasniflerden hareketle geleneksel bağlamdaki katılım aktivitelerinin, fiziksel olarak somut biçimde dâhil olunan ortamlarda gerçekleştirilebildiği söylenebilir. Nitekim oy verme davranışından, mitinglere varıncaya dek birçok katılım biçimi fiziksel olarak dâhil olunan platformlarda gerçekleştirilmektedir. Öte yandan bilişim sistemleri ve teknolojinin gelişmesi ile birlikte sanal platformlarda da katılım aktivitelerinin gerçekleştirildiği örneklere günümüzde sıkça rastlanmaktadır. Öyle ki bu platformlarda organize edilen katılım faaliyetleri toplumsal alanda güçlü dönüşümler yaratabilmekte reel dünyadaki politik alanı da ciddi biçimlerde etkileyebilmektedir. Yakın dönemlerde bu duruma somut olarak örnek gösterilebilecek olaylar arasında; elektronik oylamalar (Kshetri ve Voas, 2018), Arap baharı benzeri halk hareketleri (Eltantawy ve Wiest, 2011) ve politikacıların sanal platformlardan yurttaşlara geri bildirimde bulunarak gerçekleştirdiği aktiviteler örnek gösterilebilir. Öte yandan siyasal katılım faaliyetlerindeki düşüşün nedenlerini ele alan çalışmalarda dolaylı yollardan yeni nesil katılım biçimlerinin etkilerini gün yüzüne çıkarmaktadır (Dalton, 2008, s. 85). Söz konusu yeni nesil katılım faaliyetleri dijital katılım ya da e-katılım başlıkları altında ele alınmakta olup bu çalışma kapsamında Twitter platformu üzerinden gerçekleştirilen siyasal katılma faaliyetine yönelik bir araştırma gerçekleştirilecektir. Dolayısıyla e-katılım aktivitelerine daha yakın açıdan bakmak gerekmektedir.

\section{Katılımın Dijitalleșmesi “e-Katılım”}

Dijital teknolojilerin gelişimine paralel olarak içinde yaşadığımız çağa sanal bir uzam eklenmiş olup bireyler söz konusu bu sanal platformlarda da kendilerine yer edinmişlerdir. Gündelik hayatın sanal mecralarla iç içe geçmesiyle birlikte oluşan dijital kültür, politik alanın çehresini de değiştirmiş, yurttaşlar sanal mecralarda siyasal katılım faaliyetlerinde bulunmaya başlamışlardır. Öte yandan politik alana aktif biçimde dâhil olmak isteyen vatandaşların beklentilerine temsili demokrasinin yeterince cevap verememesi nihayetinde oluşan boşluğu dijital alanda katılıma olanak tanıyan e-katılım olanakları doldurmuştur. Hükümet organları ve halk arasındaki iletişimi karşılıklı bir boyuta taşıyan yeni iletişim teknolojileri, siyasal katılımın dijitalleşmesinde önemli bir konum teşkil etmektedir (Meriç, 2014, s. 176).

E-katılım; bilgi iletişim teknolojileri aracılığıyla vatandaşların, sivil toplum örgütlerinin ve hükümet organlarının, yönetim nezdinde alınan kararları etkileyebilmek veya ilgili kararları meşrulaştırmak amacıyla politik söylem üretmelerini ya da mevcut söylemleri desteklemelerini konu edinen katılımları ifade etmektedir (Karkın, 2012, s. 49). E-katılımı oluşturan "e (lektronik)" ögesi e-devlet, e-demokrasi gibi kavramlarla doğrudan etkileşim halindedir öte yandan internet başta olmak üzere web teknolojilerinin kullanımını ifade etmektedir. Katılım ögesi ise yukarıdaki bölümlerde de bahsedildiği üzere bir eşikten içeri geçme, dâhil olma anlamları taşımasına rağmen, e-katılım ise politik süreçler üzerine web teknolojileri üzerinden katılımı ifade etmektedir (Sæbø, Rose ve Flak, 2008, s. 402). 
E-katılım aktivitelerinden biri olan e-oylama (elektronik oylama) tarihsel anlamda ilk olarak 2001 y1lında Avustralya'da gerçekleştirilmiş olup 2007 yılında da internet üzerinden bu uygulamanın gerçekleştirildiğine rastlanmaktadır. Öte yandan e-katılıma yönelik olarak 2002 yılında İngiltere'de bazı kamu otoriteleri, seçimlerin ve politik süreçlerin modernize edilmesi maksadıyla merkezi hükümetten fon talebinde bulunmuşlardır. 2014 yılına gelindiğinde ise İtalya, Kanada, Hollanda, Estonya, Brezilya, ABD, Fransa, Avustralya ve Birleşik Krallık’ da eoylamaya dair uygulamaların gerçekleştirildiği görülmektedir (Webrazzi, 2018a). Günümüze gelindiğinde ise e-demokrasi çerçevesinde e-katılıma destek sağlayan hükümetlerin sayısında giderek bir artış yaşanmaktadır. Kurum ve kuruluşlar, kamuoyunun siyasal enformasyonlara ulaşım sağlaması ve yorumda bulunabilmesi amacıyla bu interaktif etkileşim biçimlerini sıkça tercih etmektedirler (Macintosh, 2004, s. 1).

Toplumsal, demokratik ve müzakere temalı süreçlere bilgi iletişim teknolojileri aracılığıyla katılımın genişletilmesini ve bu süreçlerin dönüştürülmesini içeren faaliyetlerin tamamı e-katılım dairesinde değerlendirilebilmektedir. E-katılım, adil ve etkin toplum dizayn için teknolojik gelişmeler vasıtasıyla katılımın özendirilmesini ve demokrasinin niteliğinin artırılması hedeflemektedir. Bu vizyon doğrultusunda hükümetler mevcut politikalarını meşrulaştırma gayreti içine girmekteyken, vatandaşlar, sivil toplum kuruluşları, baskı grupları ve lobiciler ise kendi çıkarlarına yönelik faaliyetlerde bulunabilmektedirler (Sæbø, Rose ve Flak, 2008, s. 401). E-katılımla birlikte vatandaşlar sanal dünyada netdaşlar (netizens) olarak yer edinirken, zaman ve mekân gibi sınırlamaların ötesine geçmişlerdir. Siyasal açıdan yeni yetkinlikler kazanan vatandaşlar geleneksel bağlamdaki eşik bekçilerini işlevsiz hale getirerek bireysel düşüncelerini daha geniş kitlelere ulaştırabilme firsatı yakalamışlardır. E-katılım davranışları yalnızca e-oylamadan ibaret olmayıp daha geniş aktivite alanlarını ifade etmektedir (Meriç, 2013, s 106). Bu noktada e-katılıma dair genel hatların biçimlendirilmesini ve sınıflandırılmasını konu alan Sæbø, Rose ve Flak'ın (2008) gerçekleştirdiği çalışmaya göre, ekatılım faaliyetleri; aktörler, aktiviteler, etkiler, bağlamsal faktörler ve değerlendirmelerden meydana gelen beş ayrı boyuta sahiptir (s. 417). Katılımı gerçekleştiren öznenin durumuna göre e-katılım aktörleri; yurttaşlar, politikacılar, devlet kurumları ya da gönüllü kuruluşlardan meydana gelebileceği gibi söz konusu bu aktörler e-katılım çerçevesinde; e-oylama, online politik söylem, e-aktivizm, e-danışma, e-kampanya ve e-dilekçe gibi aktiviteleri gerçekleştirebilmektedirler. Gerçekleştirilen faaliyetler, web teknolojilerinin herkese ulaştırılması, internet alt yapısının geliştirilmesi ve erişilebilirlik gibi çeşitli faktörlerle de bağlantılı olup, sivil angajman etkisi, müzakereci etki ve demokratik etki gibi etkilere sahiptir (Sæbø, Rose ve Flak, 2008).

Sæbø, Rose ve Flak'ın (2008) çizdiği bu sınıflandırma siyasal katılım faaliyetlerinin dijital uzamda yer alması açısından elzemdir. Dijitalleşen katılım davranışı, sosyokültürel, ekonomik ve siyasal alanların teknoloji ile birlikte kavramsallaştırılmasını konu edinmektedir. Yeni iletişim formları ve sosyal medya gibi pratikler bireylerin yaşam şartlarını kolaylaştırmış bu bağlamda katılım faaliyetlerine dair aktörler ilgili platformlarda yukarıdaki sınıflandırma çerçevesinde boy göstermeye başlamışlardır (Meriç, 2014, s. 176). Çalışma kapsamında ekatılım davranışı bir sosyal medya platformu olan Twitter üzerinden ele alınacağından Twitter'in sunduğu etkileşim olanaklarına ve sahip olduğu platform kimliğine değinmek gerekmektedir. Nitekim Twitter, ortaya çıktığı anlardan itibaren diğer sosyal platformlara 
nazaran demokratik süreçlerle ilgili olarak daha fazla politik niteliği bünyesinde barındıran bir yapıya sahiptir.

\section{Bir E-katılım Platformu Olarak Twitter}

Twitter, çeşitli formal ve informal kaynaklardan edinilen verilerin online olarak yayılmasını sağlayan sosyal platformlardan birisidir. Kişilerin gündelik yaşamlarındaki anlık aktivitelerinin ve düşüncelerinin paylaşılmasını sağlayan bir mikro-blog olarak tasarlanmıştır. 2008 yılında gerçekleşen Kaliforniya orman yangınlarında ve başkanlık seçimlerinde, 2009 yılında İran'da ki seçim protestolarını organize etme gibi önemli etkinliklerde, etkileşim kurulmasına olanak tanıyan bir mecra olarak ön plana çıkmıştır. Öte yandan Amerika Birleşik Devletleri Dış İşleri Bakanlığı'nın İran'daki protestoları koordine etmek maksadıyla Twitter'a rutin bakımlarını ertelemesi yönündeki talebi de (Hermida, 2014, s. 297) Twitter'in ortaya çıktığı ilk yıllardan itibaren politik bir etkiye sahip olduğunu kanıtlar niteliktedir. Gerek politik amaçların inşasında (Karagöz, 2013, s.137-139) gerek siyasal temalı taleplerde (Hermida, 2014) Twitter, siyasal imaj ile özdeşleşen bir kimliğe sahiptir. Dolayısıyla e-katılıma olanak tanıyan bir platform olarak ön plana çıkmaktadır.

İçinde yaşadığımız yüzyılın en popüler mikro-blogu olarak tanınan Twitter, platformun kurucuları tarafından dinamik bir yapıya sahip olması yönleriyle ön plana çıkarılmaktadır. Öyle ki kurucuların platformu nasıl tanımladıkları sorulduğunda Jack Dorsey ve ekibi; "Bir tanım yapılacaksa biz ancak bu tanımlamanın \%1'ini yapabiliriz, tanım katılımcıların içinde yaşadıkları ana yönelik paylaşımlarıyla ve kullanıcıların görüşleriyle kendisini tamamlayacaktır" şeklinde beyan vermektedirler (Sagolla, 2009, s. xii). Milyonlarca insanın her gün atmış olduğu "cıvıldama" anlamına gelen anlık tweetler 14 kişilik bir ekibin Jack Dorsey'in önerisini değerlendirmesi sonucunda ortaya çıkmıştır. Dorsey'in önerisi bireylerin anlık aktivitelerini SMS yoluyla geniş kitlelere ulaştırılabilmesini konu almaktaydı. 21 Mart 2006 yılından itibaren yayın hayatına başlayan Twitter günümüzdeki felsefe anlayışına ve biçimine sahip olana dek çeşitli aşamalardan geçmiştir (HowTwiterWasBorn, 2018a). Bu gelişim serüveni kısaca; "kullanıcı sayısının artması", "ünlülerin ve politikacıların platforma dâhil olması", "şirketlerin kendilerine yönelik değerlendirmelere cevap verebilmeleri amacıyla platforma dâhil olması" gibi kritik aşamalardan meydana gelmektedir (Sagollo, 2009). Öte yandan 140 karakterle sınırlı olarak paylaşım yapılmasına olanak sağlayan Twitter bu sinırlamayı 240 karakter olarak genişletmiştir.

Platformun gelişim serüveni içerisinde bazı hadiseler e-katılım açısından dikkat çekmektedir. Bu olayların başında 16 Nisan 2008 tarihinde Kaliforniya'lı foto muhabiri James Buck'ın Mısır seyahati sırasında yanlış bir anlaşılmadan dolayı tutuklanması ve akabinde "tutuklandım" şeklinde tweet atması gelmektedir (Sagollo, 2009, s. xxii-xxiv). Bu tweetin ardından ABD yetkilileri devreye geçerek ertesi gün James Buck serbest bırakılmıştır. Yaşanan bu gelişme nihayetinde Twitter ulusal ve uluslararası camiada kendisine oldukça geniş bir yer bulmuştur. Sadece birkaç karakterden oluşan bir metnin bu denli güçlü bir etki uyandırması politik alan için onun güçlü bir iletişim aracı olduğunu teyit etmiştir (Sagollo, 2009, s. xxivxxv). Öte yandan 2009 yılına gelindiğinde Barack Obama'nın başkan yardımcısının Joe Biden olacağını Twitter üzerinden ilan etmesiyle birlikte platformun kamuoyuna ulaşma noktasında etkili bir mecra olduğu ve siyasal iletişim aracı olarak kullanıldığı bir kez daha ortaya konulmuştur (Sagolla, 2009: xxv-xxvi). Bu kapsamda ampirik araştırmalar için giderek önemi 
artan bir platform haline gelen Twitter, 2015 yllından itibaren 300 milyondan fazla aktif abonesiyle ve bu kullanıcıların günlük atmış olduğu 500 milyondan fazla tweetle diğer sosyal platformlardan özel bir şekilde ayrılmaktadır. Söz konusu özellik, Twitter'in anonim hesapların birbiri ile etkileşime geçebilmesine olanak sağlamasından, paylaşımlar arasında bağlantı kurulmasına imkân tanımasından (Newman, 2017, s. 816) ve yukarıda bahsi geçen olaylardan kaynaklanmaktadır.

Platformun varoluş amacından ve gelişim hikâyesinden de çıkarımlanacağı üzere şirket bir takım kurumsal değerleri ön planda tutmaktadır. Bunların başında ifade özgürlüğü gelmektedir. Dünya çapında devlet yetkilileriyle, politikacılarla ve sivil toplum kuruluşları ile kamu politikaları çerçevesinde etkileşim kurmayı amaçlayan Twitter, şeffaf yönetim anlayışına vurgu yaparak yılda iki kez şeffaflık raporu yayınlamaktadır (TwitterAbout, 2018a). 2018 yılı itibariyle dünya çapında 330 milyon kişinin Twitter kullandığı göz önünde bulundurulduğunda platformun sosyal ve toplumsal gelişmelere, azınlık haklarına ve medya okuryazarlığı gibi değerlere önem atfetmesi oldukça manidardır. Dolayısıyla e-katılım açısından ve çoğulcu demokrasi anlayışı bağlamında Twitter siyasal iletişim için önemli bir merkezde yer almaktadır. $\mathrm{Bu}$ noktada platformun sunmuş olduğu etkileşim olanakları; tweet atma, direkt mesaj gönderme, takip etme, hashtag bağlantılar ile paylaşım yapabilme, retweet etme, kullanıcı adının başına @ işareti getirerek ileşimleme (mention), anket yapma, paylaşılan gönderileri beğenme ve canlı yayın yapabilme şeklindedir.

\section{Benlik Saygısı ve Twitter’da E-Katılım İlişsisine Yönelik Arka Plan}

Boyd ve Ellison'a (2008) göre sosyal platformların tasarlanış amacı kişilerin benlik sunumlarını gerçekleştirebilmeleridir. Bu bağlamda bireylerin dâhil olduğu sanal platformlarda da kendi benlikleri doğrultusunda aktivitelerde bulunduğu düşünülmektedir. Alan yazında gerçekleştirilen kimi çalışmalar bu varsayımı desteklemektedir. Örneğin cinsiyet, grup kimliği ve kollektif benlik saygısının katılımcıların sosyal ağ sitesi kullanımı üzerindeki etkisinin ele alındığı bir araştırmada benlik saygısı yüksek katılımcıların sosyal ağlar vasıtasıyla kurdukları iletişimde motivasyonlarının yüksek seyrettiği görülmüştür. Öte yandan benlik saygısı düşük bireylerin ise gündelik yaşamda kuramadıkları iletişimi sosyal mecralar aracılığıyla ikame ettiği, ait oldukları sosyal sınıflar ile bu şekilde özdeşim kurdukları belirtilmektedir (Barker, 2009, s. 212-213). Benzer şekilde bir diğer araştırmada katılımcıların iyi olma durumları ve benlik saygıları açısından MySpace ve Frienster gibi sosyal platformları kullanma biçimleri incelenmiş olup araştırma sonunda bireylerin sosyal ağ kullanma durumlarıyla benlik saygıları arasında anlamlı ilişkiler tespit edilmiştir. Sosyal sitelerden alınan olumlu ve olumsuz geri bildirimlerin benlik saygısını etkilediği belirtilmektedir (Valkenburg, Peter, Schouten, 2006, s. 589). Bahsi geçen çalışmalarda da görüldüğü üzere bireylerin benlik saygısı ile sosyal medya kullanımları arasında anlamlı bir ilişki ve etki söz konusudur.

$\mathrm{Bu}$ kapsamda bireylerin Twitter platformunda gerçekleştirdikleri aktiviteler ile benlik saygıları arasında anlamlı bir ilişki olduğu varsayılmaktadır. Öte yandan çalışmanın kavramsal arka planında sıkça bahsedildiği üzere Twitter'in politik alanla olan ilişkisi göz önünde bulundurulduğunda Twitter'da gerçekleştirilen e-katılım davranışı ile benlik saygısı arasındaki olası bir anlamlı ilişki gerek e-katılım gerek benlik saygısı literatürü açısından önem taşımaktadır. Literatürde daha önce benlik saygısı ve e-katılım değişkenlerinin ilişkilendirildiği bir modele rastlanmamıştır. Bu nedenle konuyla ilgili benzer çalışmalar üzerinden araştırma 
değişkenleri arasındaki ilişkiye yönelik kavramsal dayanaklar ifade edilmeye çalışılmaktadır. Bu doğrultuda Wilcox ve Stephan'ın (2013) çevrimiçi ortamlarda gerçekleştirilen paylaşımları yakın ve güçlü ilişkiler bazında değerlendirdiği araştırma yerinde bir örnek teşkil etmektedir. Nitekim ilgili çalışmada bireylerin sosyal mecralarda gerçekleştirdikleri paylaşımlarda yakın ve güçlü ilişkilerini göz önünde bulundurduğu ifade edilmektedir. Güçlü bağlar tarafindan kendi gönderilerinin irdelendiğini düşünen katılımcıların benliklerini sunarken çeşitli filtreler ile paylaşımlarına müdahalelerde bulundukları belirtilmektedir. İlgili müdahalelerden de anlaşılacağı üzere bireyler yakın ve güçlü bağlarına önem atfetmektedirler. Benlik saygısının ele alındığı bölümden hatırlanacağı üzere bireylerin önem atfettikleri olgular ile benlik saygıları arasında güçlü bir bağ söz konusudur (Tatl1, 2012, s. 15). Bu bağlamda benlik saygısı (BS) değişkeni ile Twitter'da Siyasal Katılım değişkenlerine yönelik alt boyutlar arasında gerçekleşmesi muhtemel ilişkiler araştırmayı e-katılım açısından cazip kılmaktadır. Bahsi geçen bilgiler ve kavramsal dayanaklar ışığında bu araştırmanın temel problemini eğitim seviyesi yüksek bir zümreyi temsil eden akademisyenlerin benlik saygları ve Twitter'da gerçekleştirdikleri siyasal katılım faaliyetleri arasındaki ilişki oluşturmaktadır.

Akademisyenlerin çalışma grubu olarak seçilmesinde eğitim faktörü önemli bir etken olmuştur. Nitekim literatürde eğitim faktörünün artması ile bireylerin, siyasal katılım faaliyetlerinin (Almond ve Verba, 1963, s. 265; Achen, 1975, s. 1218; Sabucedo ve Arce, 1991, s. 93; Eroğul, 1991, s. 108; Galston, 2004, s. 264) ve benlik saygılarının (Özkan, 1994, s. 6-7; Çetinkaya vd., 2006, s.119; Baybek ve Yavuz, 2005, s. 93-94; Özgüngör ve Paksu, 2017, s. 118119) artacağı öngörülmektedir. Dolayısıyla çalışma sonucunda katılımcıların benlik saygılarının ve e-katılım durumlarının genel kanaat ile örtüşüp örtüşmeyeceği de merak uyandırmaktadır.

\section{Yöntem}

Gerçekleştirilen uygulamada kantitatif araştırma metotlarından anket (survey) tekniği kullanılmıştır. Bu başlık altında araştırmanın evreni, örneklemi, modeli, veri toplama araçları ve verilerin analiz edildiği istatistiki testlere yönelik bilgiler yer almaktadır.

\section{Çalışma Grubu}

Araştırmanın soyut evreni, Türkiye Cumhuriyeti içinde akademisyenlik mesleğini icra eden akademisyenlerden oluşturmaktadır. Öte yandan araştırmanın, ulaşılması mümkün dairede yer alan çalışma evrenini ise (Karasar, 1984: 115-116) Uşak Üniversitesi, Gümüşhane Üniversitesi ve Süleyman Demirel Üniversitesi akademisyenleri oluşturmaktadır. İlgili çalışma evreni URAP'ın (University Ranking by Academic Performance) 2018 yılı için yapmış olduğu akademik başarı sıralaması dikkate alınarak oluşturulmuştur. Sıralamada 157 üniversite akademik başarı kriteri açısından; başarı seviyesi yüksek, orta ve düşük şeklinde 3 ayrı kategoriye bölünmüştür. 1. ve 52. sıralama arasında kalan üniversiteler başarı seviyesi yüksek, 53. ve 105. sıralama arasında kalan üniversitelerin başarı seviyesi orta, 106. ve 157. sıralama arasında yer alan üniversitelerin başarı seviyesi düşük olarak nitelendirilmiştir. Böylece başarı seviyesi açısından her üç kümeyi temsilen ulaşımı kolay birer üniversite çalışma evrenine dâhil edilerek, seçilecek örneklemlerin evreni temsil etme gücünü artırmak amaçlanmıştır. Nitekim literatürde belirtildiği üzere benlik saygısı ve başarı seviyesi yakından ilişkili faktörlerdir (Harter, 1993: 88-91; Tatl1, 2012: 15). Dolayısıyla seçilecek örneklemin benlik saygısı açısından 
çalışma evrenini ve soyut evreni temsil etme yetisi dengelenerek araştırma verilerinin güvenilirliğini artırmak amaçlanmıştır (Büyüköztürk, 2012: 3).

Çalışmanın örneklemi ise katılımcıların cinsiyet ve unvan açısından birbirinden bağımsız ve her kümenin eşit temsil edilebilmesi maksadıyla, tabakalı örnekleme usulüyle seçilmiştir. Bu bağlamda çalışma evrenini oluşturan 3653 kişi içinden 503 katılımcı tesadüfi yöntemle seçilerek araştırma verileri bu grup üzerinden toplanmıştır.

\section{Veri Toplama Araçları}

Araştırma verileri kantitatif araştırma metotlarından anket tekniği ile toplanmıştır. İlgili anket formu, Rosenberg'in Benlik Saygısı Ölçeği (RBSÖ), Twitter'da Siyasal Katılım Ölçeği (TSKÖ) ve Kişisel Bilgi Formu (KBF) dâhilinde yer alan sorulardan oluşmaktadır.

\section{Rosenberg'in Benlik Saygısı Ölçeği (RBSÖ)}

RBSÖ, ABD'de 1963 y1lında Morris Rosenberg tarafından 5024 lise öğrencisi üzerinde geliştirilmiştir. Ölçeğin ülkemizdeki geçerlilik ve güvenilirlik çalışmaları Çuhadaroğlu (1986) tarafından 205 kişilik lise öğrencisi üzerinde yapılmıştır. Rosenberg (1965) tarafından yapılan çalışmada ölçeğin benlik saygısı boyutu için test-tekrar test güvenilirliği .75, geçerlilik katsayısı .71 olarak bulunurken ölçeğin geneline yönelik test-tekrar test katsayısının .82-.88, iç tutarlılık katsayısının ise $.77-.88$ arasında değiştiği tespit edilmiştir. Çuhadaroğlu'nun gerçekleştirdiği geçerlilik ve güvenilirlik çalışmasında ise test-tekrar test katsayısının 48 ile.79 arasında değiştiği görülmüştür. Öte yandan RBSÖ'nün evrensel kültüre uygunluğunun sinandiğı bir çalışmada Schmitt ve Allik (2005), 28 farklı dilde 53 farklı ulustan 16.998 kişinin katılımıyla bir araştırma gerçekleştirmişler, araştırma sonucunda RBSÖ’nün yüksek geçerlilik ve güvenilirlik değerleriyle evrensel bir ölçek olduğu sonucuna ulaşmışlardır.

RBSÖ 63 maddenin 12 alt boyuta ayrıldığı bir yapıya sahiptir. Çalışma kapsamında ölçek, orijinal formdaki oranlar korunarak likert tarzında yapılandırılmış olup güvenilirliği düşüren sorular formdan atılmıştır. Dolayısıyla araştırma kapsamında çalışmanın amac1 doğrultusunda 8 alt boyut tercih edilmiş olup bu çalışma kapsamında ulaşılan güvenilirlik değerleri şu şekildedir. Benlik saygısı $\alpha=.829$, kendilik kavramı sürekliliği $\alpha=.728$, insanlara güven duyma $\alpha=.587$, eleştiriye duyarlılı $\alpha=.655$, depresif duygulanım $\alpha=.786$, hayalperestlik $\alpha=.860$, kişilerarası ilişkilerde tehdit hissetme $\alpha=.707$, tartışmalara katılabilme $r=.348$ $(p<0,01), R B S O ̈$ 'nün geneline yönelik güvenilirlik katsayısı ise $\alpha=.707$ olarak hesaplanmıştır. Gerçekleştirilen iç tutarlılık analizi sonucunda $0.60 \geq \alpha>0.90$ arasındaki değerlerin oldukça güvenilir, $0.40 \geq \alpha>0.60$ arasındaki değerlerin ise güvenilir olduğu kabul edilmektedir (Can, 2018, s. 391). İç tutarlılık analizi yöntemlerinden bir diğeri olan korelasyon analizi (r) ile hesaplan tartışmalara katılabilme alt boyutunun ise $\mathrm{r}=, 348(\mathrm{p}<0.01)$ değerinde güvenilir olduğu görülmektedir (Çakmur, 2012, s. 340-341).

\section{Twitter'da Siyasal Katılım Ölçeği (TSKÖ)}

TSKÖ Twitter'da gerçekleştirilen siyasal katılım davranışlarını ölçmek amacıyla 5'li likert tarzında geliştirilmiştir (Güler ve Sezgin, 2019). Siyasal ifade, politika takibi, yerel yönetime katılım/yardım, propaganda yürüyüş/grev ve siyasal tartışmalara katılım olmak üzere beş alt boyuta sahiptir. Çalışma kapsamında ölçeğin geneline yönelik güvenilirlik katsayısı $\alpha=.94$ 
olarak hesaplanırken alt boyutlara ait güvenilirlik değerleri .81 ile .92 arasında değişmektedir. Ölçeğin yapı geçerliliği faktör analizi ile teyit edilmiştir.

\section{Kişisel Bilgi Formu (KBF)}

KBF'de katılımcıların akademik çalışma alanı, akademik unvanı, yaşı, cinsiyeti, medeni durumu gibi demografik bilgilerine yönelik sorular yer almaktadır.

\section{Verilerin Analizi}

Elde edilen veriler ( $\mathrm{n}>30)$ basıklık ve çarpıklık açısından -1.96 ile +1.96 arasında seyrederek normallik koşulunu sağlamaktadır (Can, 2014: 85) dolayısıyla homojen olduğu da görülen verilere SPSS 24.0 paket programıla parametrik testler uygulanmıştır. $\mathrm{Bu}$ kapsamda değişkenler arasındaki ilişki Pearson Korelasyon katsayısı hesaplanarak analiz edilirken değişkenler arası farklılaşmaya dair durumlar ANOVA ve Independent Samples T Testleri ile değerlendirilmiştir. ANOVA testi çerçevesinde anlamlı olarak farklılık gösteren ikili gruplar arasındaki farklar Tukey Testi ile irdelenmiştir. Öte yandan katılımcıların demografik durumlarına dair verdikleri yanıtlar ve kategorilere ayrılan RBSÖ alt boyutlarına dair düzeyler Frekans Analizi ile betimlenmiştir.

\section{Bulgular}

Frekans analizi nihayetinde ulaşılan bulgulara göre akademisyenlerin ( $\mathrm{n}=503) \% 49,5$ 'i kadın, $\% 50,5$ 'i ise erkektir. Katılımcıların çalışma alanları, \%49,1 ile fen bilimleri, \%41 ile sosyal bilimler, \%3,6 ile sağlık bilimleri, \%3,2 ile güzel sanatlar ve \%3,2 ile diğer alanlar olarak dağılım göstermektedir. Çalışmaya geribildirimde bulunan akademisyenler unvan olarak ise; \% 30,2 ile doktor ögretim üyesi kadrosunda, \%28,6 ile araştırma görevlisi kadrosunda, \%12,5 ile öğretim görevlisi kadrosunda, \%11,7 ile profesör kadrosunda, \%11,5 ile doçent kadrosunda, \%5,4 ile diğer olarak tanımlanan akademik kadrolarda faaliyet göstermektedir. Öte yandan akademisyenlerin yaş olarak \%38,2 ile 35-44 yaş aralığında yoğunlaştı̆̆ 1 sonucuna ulaşıllırken bu sıralamayı $\% 36,4$ ile $25-34, \% 18,3$ ile $45-54, \% 4,2$ ile 55 ve üzeri, $\% 3$ ile 24 ve altındaki yaş aralığına sahip olan akademisyenler takip etmektedir. Katılımcılar medeni hallerine göre ise $\% 54,9$ 'u evli, \%40,8'i bekâr ve \%4,4'ü daha önce evlilik yaşayıp ayrılmış kişilerden oluşmaktadır.

Katılımcıların RBSÖ dâhilinde \%87,9'u yüksek, \%12,1'i ise orta düzey benlik saygısına sahiptir. Benlik saygısı düşük kategorisinde herhangi bir katılımcı yer almamıştır. Kendilik kavramının sürekliliği açısından akademisyenlerin $\% 87,5$ 'inin kendilik kavramı sürekliliği fazla, \%12,5'inin ise azdır. Hayalperestlik bağlamında \%55,9'lik çoğunluğun orta düzey hayalperest olduğu, \%25,4'lük kesimin düşük düzeyde hayalperest olduğu ve \%18,7'lik kesimin ise yüksek düzeyde hayalperest olduğu görülmektedir. Kişilerarası ilişkilerde hissedilen tehdide göre ise $\% 58,1^{\prime}$ lik çoğunluğun orta düzeyde tehdit hissettiği, $\% 33,4$ 'lük dilimin yüksek düzeyde tehdit hissettiği ve $\% 8,8^{\prime}$ lik bir kümenin düşük düzeyde tehdit hissettiği sonucuna ulaşılmıştır. Diğer yandan katılımcıların eleştiriye karşı hassas olmalarını ve çekingenlik göstermelerini konu alan eleştiriye karşı duyarlılık bağlamında ise \%66'lık bir kesiminin orta seviyede, $\% 31,6$ 'lik kesimin yüksek düzeyde ve \%2,4'lük kesimin ise düşük düzeyde hassas olduğu tespit edilmiştir. Öte yandan akademisyenlerin \%80,7'sinin insanlara güven duyma konusunda orta düzeyde bir güvene sahip olduğu, \%10,7'sinin düşük düzeyde bir güvene sahip olduğu, $\% 8,5$ 'inin ise yüksek düzeyde güvene sahip olduğu görülmektedir. Tartışmalara katılabilme 
hususunda ise $\% 60,8^{\prime}$ lik bir oran yüksek seviyede, $\% 35,8^{\prime}$ lik oran orta düzeyde, $\% 3,4$ 'lük bir kesim ise düşük düzeyde bir tutuma sahiptir.

P: Araştırmanın temel problemine yönelik RBSÖ ve TSKÖ değişkenleri arasında gerçekleştirilen Pearson Korelasyon analizine dair sonuçlar aşağıdaki tabloda gösterilmektedir.

Tablo 1. Katılımcıların Benlik Saygısı ve Twitter'da Siyasal Katılım Davranışları Arasındaki İlişki Durumları (N=503)

\begin{tabular}{lcccc}
\hline & $\begin{array}{c}\text { Siyasal } \\
\text { İfade }\end{array}$ & $\begin{array}{c}\text { Siyasal } \\
\text { Tartı̧ma }\end{array}$ & $\begin{array}{c}\text { Politika ve } \\
\text { Hizmet Takip }\end{array}$ & $\begin{array}{c}\text { Yerel Yönetime } \\
\text { Katılım }\end{array}$ \\
\hline Benlik Saygısı & $-.178^{* *}$ & $-.106^{*}$ & & $-.135^{* *}$ \\
$\begin{array}{l}\text { Kendilik Kavramı } \\
\text { Sürekliliği }\end{array}$ & $-.224^{* *}$ & $-.160^{* *}$ & & $-.171^{* *}$ \\
$\begin{array}{l}\text { İnsanlara Güven } \\
\text { Duyma }\end{array}$ & & & & \\
$\begin{array}{l}\text { Eleştiriye Duyarlılık } \\
\text { Depresif Duygulanım }\end{array}$ & & & & \\
$\begin{array}{l}\text { Hayalperestlik } \\
\text { Kişilerarası İlişkilerde }\end{array}$ & $.164^{* *}$ & & & \\
$\begin{array}{l}\text { Tehdit Hissetme } \\
\text { Tartışmalara }\end{array}$ & & $.094^{*}$ & & $.160^{* *}$ \\
Katılabilme & $.110^{*}$ & & & \\
\hline
\end{tabular}

RBSÖ dâhilinde katılımcıların benlik saygıları ile TSKÖ altında yer alan "siyasal ifade" $(\mathrm{r}=-.178 ; \mathrm{p}<.01)$, "siyasal tartışma" $(\mathrm{r}=-.106 ; \mathrm{p}<.05)$ ve "yerel yönetime katılım" $(\mathrm{r}=-.135$; $\mathrm{p}<.01)$ alt değişkenleri ile negatif yönde düşük düzeyde anlamlı ilişki olduğu tespit edilmiştir. Katılımcıların benlik saygılarının artmasıyla Twitter mecrasında siyasal ifadede bulunma, siyasal tartışmalara katılma ve yerel yönetimle ilgili faaliyetlere katılma durumlarının azaldığ söylenebilir. Bir diğer RBSÖ değişkeni olan "kendilik kavramı sürekliliği” ile TSKÖ’ye ait "siyasal ifade" $(\mathrm{r}=-.224 ; \mathrm{p}<.01)$, "siyasal tartı̧̧ma" $(\mathrm{r}=-.160 ; \mathrm{p}<.01)$ ve "yerel yönetime katılım” ( $\mathrm{r}=-.171 ; \mathrm{p}<.01)$ alt değişkenleri arasında da negatif yönde anlamlı ilişki olduğu görülmektedir. $\mathrm{Bu}$ sonuçtan hareketle akademisyenlerin "kendilik kavramlarının sürekli" olmasına dair puanlarının artmasıyla Twitter'da gerçekleştirdikleri siyasal ifadede bulunma, siyasal tartışmalara katılma ve yerel yönetime katılma puanlarının azalacağı sonucuna ulaşılmaktadır. Burada bir parantez açarak, katılımcıların \%87,5'inin kendilik kavramı sürekliliklerinin fazla olduğunu hatırlatmak gerekmektedir. Kendilik kavramının sürekliliği bireylerin uzun bir süre zarfında kendileri ile tutarlı davranışlar sergilemesini ifade etmektedir. Nitekim akademisyenlerin benliklerini, uzun vadede tutarlı ve kolay değişmeyen bir yapıya sahip olarak tanımlamalarıyla siyasal katılım durumları arasındaki ilişkinin negatif yönde gerçekleşmesi, akademisyenlerin geçmişten beri uzun bir süre boyunca siyasal katılıma dair (Twitter'da) pasif davranışlar sergileme tutumu gösterdiklerini işaret etmektedir. "Hayalperestlik" alt boyutu ise TSKÖ’ye dair, "siyasal ifade" ( $r=.164 ; \mathrm{p}<.01)$, "siyasal tartışmalara katılabilme" ( $\mathrm{r}=.094 ; \mathrm{p}<.05)$, ve "yerel yönetime katılım" $(\mathrm{r}=.160 ; \mathrm{p}<.01)$, alt boyutlarıyla pozitif yönde anlamlı ilişki arz etmektedir. $\mathrm{Bu}$ bulgudan hareketle akademisyenlerin hayalperestlik düzeylerinin artması ile Twitter'da siyasal katılım düzeylerinin de artacağı öngörülmektedir. "Tartışmalara katılabilme" alt boyutunun da TSKÖ altında yer 
alan , "siyasal ifade" $(\mathrm{r}=.110 ; \mathrm{p}<.05)$, "siyasal tartışma" $(\mathrm{r}=.091 ; \mathrm{p}<.05)$, "politika ve hizmet takibi” ( $\mathrm{r}=.141 ; \mathrm{p}<.01)$, "yerel yönetime katılım $(\mathrm{r}=.097 ; \mathrm{p}<.01)$ " değişkenlerinin tümüyle pozitif yönde oldukça düşük bir seviyede anlamlı ilişki içinde olduğu görülmüştür. Katılımcıların tartışmalara katılabilme puanlarının artmasıyla siyasal tartışmalara katılabilme, yerel yönetime katılabilme ve siyasal ifadede bulunabilme durumlarının da artmas1 beklenmektedir.

p1-p2: Akademisyenlerin benlik saygıs1 (p1) ve Twitter'da siyasal kat1lım düzeylerine (p2), yönelik ortalamaları ise aşağıdaki tabloda aktarıldığı gibidir.

Tablo 2: Akademisyenlerin Benlik Saygısı ve Twitter'da Siyasal Katılım Düzeyleri

\begin{tabular}{|c|c|c|c|c|c|c|c|c|}
\hline \multirow{3}{*}{ Benlik Saygısı (BS) } & \multirow{2}{*}{ Min } & \multirow{2}{*}{ Max. } & \multirow{2}{*}{$\mathrm{X}$} & \multirow{2}{*}{$\mathrm{Sd}$} & \multicolumn{2}{|c|}{ Skewness } & \multicolumn{2}{|c|}{ Kurtosis } \\
\hline & & & & & Statistic & Std. E. & Statistic & Std. E. \\
\hline & 1,90 & 5,00 & 4,11 & ,61076 &,- 690 & ,109 & ,126 & 217 \\
\hline Kendilik Kavramı Sürekliliği & 1,00 & 5,00 & 3,37 &, 78331 &,- 145 &, 109 &,- 309 & ,217 \\
\hline RHayalperestlik & 1,00 & 5,00 & 2,30 & 1,00335 & 610 & ,109 &,- 213 & 217 \\
\hline BKişilerarası İlişki. Tehdit H. & 1,00 & 5,00 & 2,79 & 89953 &,- 015 & , 109 &,- 379 & 217 \\
\hline S Eleştiriye Duyarlılık & 1,00 & 5,00 & 2,85 & ,77839 & 212 &, 109 &,- 182 &, 217 \\
\hline ÖDepresif Duygulanım & 1,00 & 5,00 & 3,49 & 64378 &,- 367 &, 109 &, 575 &, 217 \\
\hline İnsanlara Güven Duyma & 1,00 & 4,75 & 2,41 & 64561 & ,268 & ,109 & ,176 & 217 \\
\hline Tartışmalara Katılabilme & 1,00 & 5,00 & 3,29 & ,71632 &,- 685 &, 109 & ,646 & 217 \\
\hline T Siyasal İfade & 1,00 & 4,00 & 1,61 & 69877 & 1,166 & 109 & ,608 & 217 \\
\hline S Siyasal Tartışmalara Katılım & 1,00 & 4,18 & 1,96 & ,80305 & ,555 & ,109 &,- 631 &, 217 \\
\hline KPolitika/Hizmet Takip & 1,00 & 5,00 & 3,06 & 1,10722 &,- 601 & ,109 &,- 762 & ,217 \\
\hline ÖYerel Yönetime Katılım & 1,00 & 4,67 & 1,58 &, 77082 & 1,327 &, 109 & 1,284 & 217 \\
\hline
\end{tabular}

Ulaşılan değerlere göre katılımcıların genel olarak RBSÖ’ye ait; BS düzeyleri $(x=4,11)$, kendilik kavramı süreklilikleri $(\mathrm{x}=3,37)$ ve depresif duygulanım açısından mutlu olma durumları $(x=3,49)$ yüksek düzeyde seyretmektedir. Diğer taraftan hayalperest olma durumlarının $(\overline{\mathrm{x}}=2.30)$, kişilerarası ilişkilerde hissettikleri tehdidin $(\overline{\mathrm{x}}=2.79)$, eleştiriye karşı duyarlılıklarının $(\overline{\mathrm{x}}=2.85)$ ve güven düzeylerinin $(\overline{\mathrm{x}}=2.41)$ orta seviyelerde olduğu saptanmıştır. Akademisyenlerin TSKÖ'ye dair durumları ele alındığında ise siyasal katılım puanlarının genel olarak düşük olduğu $(\overline{\mathrm{x}}=1.61 ; 1.96 ; 1.58)$ yalnızca politika ve hizmet takibi konusunda Twitter'da aktif oldukları $(\overline{\mathrm{x}}=3.06)$ sonucuna ulaşılmıştır.

p3: RBSÖ bazında TSKÖ açısından farklılaşma durumları ise şu şekildedir;

Akademisyenlerin (t-testi) benlik saygıları ve kendilik kavramlarının süreklilikleri açısından; siyasal ifadede bulunma, siyasal tartışmalara katılma, politika hizmet takibi ve yerel yönetime katılma konularında anlamlı olarak ( $>0.05)$ farklılaşmadığı görülmüştür. Hayalperestlik açısından ise siyasal ifadede bulunma $(\mathrm{F}=9,392 ; \mathrm{p}<.05)$ ve yerel yönetime katılma $(\mathrm{F}=7,618 ; \mathrm{p}<.05)$ konularında farklılaştıkları saptanmıştır. İkili gruplar arasındaki anlamlı farklılıklar (Tukey) irdelendiğinde hayalperestlik seviyesi yüksek katılımcıların (,37554*) düşük seviyedekilere göre daha aktif siyasal ifadede bulunduğu düşünülmektedir. Yerel yönetime katılım noktasında da benzer şekilde hayalperestlik seviyesi yüksek akademisyenler (,39024*) düşük olanlara nazaran daha üst ortalama ile farklılaşmaktadır. Bu kapsamda hayalperestlik seviyesi yüksek akademisyenlerin siyasal ifadede bulunma ve yerel 
yönetime katılma hususlarında hayalperestlik düzeyi az olanlara göre daha aktif rol aldığ 1 sonucuna ulaşılmaktadır. Eleştiriye karşı duyarlılık noktasında da katılımcılar, siyasal ifadede bulunma açısından anlamlı olarak $(\mathrm{F}=3,807 ; \mathrm{p}<.05)$ farklılaşmaktadırlar. İkili gruplar arasındaki farkl11ıklar (Tukey) incelendiğinde eleştiriye duyarlılık düzeyi düşük bireyler, orta (,55530*) ve yüksek $\left(, 50484^{*}\right)$ seviyedeki bireylere nazaran siyasal ifadede bulunma noktasında daha faaldirler. Doğal bir öngörüyle de eleştirilere karşı çekingen olmayan kişilerin daha özgürce siyasal ifadede bulunacağı beklenmektedir. Öte yandan katılımcıların depresif duygulanım, insanlara güven duyma, tartışmalara katılabilme ve kişilerarası ilişkilerde tehdit hissetme açısından (ANOVA) TSKÖ’ye ait alt değişkenler bazında istatistiki yönden farklılaşmadığı görülmüştür $(\mathrm{p}>0.05)$.

p4: Katılımcıların demografik faktörler bazında "BS, Hayalperestlik ve TSKÖ alt değişsenleri” açısından farklılaşım durumları ise şu şekildedir;

Katılımcıların demografik durumlarına göre ise akademik unvan $(\mathrm{F}=7,504)$ yaş $(\mathrm{F}=11,083)$ ve medeni durum $(\mathrm{F}=3,183)$ faktörleri bazında benlik saygısı açısından farklılaştığı görülmüsstür $(\mathrm{p}<0.05)$. Bu kapsamda ikili gruplar arasındaki farklılıklar (Tukey) ele alındığında akademik unvan açısından profesörlerin $\left(, 41888^{*}\right)$, doçentlerin $\left(, 33209^{*}\right)$ ve doktor öğretim üyelerinin $\left(, 21330^{*}\right)$ BS düzeyleri, araştırma görevlilerinin BS düzeylerinden yüksektir. Yaş faktörü açısından ise 24 ve altı bir yaşa sahip akademisyenlerin benlik saygısı, kendilerinden büyük akademisyenlere göre daha düşük bir seviyede konumlanmaktadır. Öte yandan 24 ve altı yaş grubundaki akademisyenlerin BS düzeyi ile diğer gruplar arasındaki fark, üst yaş gruplarına çıkıldıkça artarak açılmaktadır. Dolayısıyla akademisyenlerin yaşının artması ile BS düzeyinin yükseldiği görülmektedir. Bu durum 25-34 yaş arasında bir yaşa sahip katılımcılar içinde aynıdır. Medeni durum bağlamında ise evli akademisyenler benlik saygısı açısından bekâr akademisyenlere göre daha üst $\left(, 13999^{*}\right)$ bir seviyede konumlanmaktadır. Daha önce evlilik deneyimlemiş olan katılımcıların ise BS düzeyi açısından evli yâda bekâr akademisyenlere göre herhangi bir farklılaşma yaşamadı $\breve{g} 1$ tespit edilmiştir.

Katılımcıların demografik durumlarına göre, çalışma alanı $(\mathrm{F}=3,576)$ akademik unvan $(\mathrm{F}=3,117)$ yaş $(\mathrm{F}=4,037)$ ve medeni durum $(\mathrm{F}=6,905)$ faktörleri bazında hayalperestlik açısından farklılaştığı görülmüştür $(\mathrm{p}<0.05)$. İkili gruplar arasındaki anlamlı farklılıklar (Tukey) irdelendiğinde çalışma alanına göre sosyal $\left(-, 89381^{*}\right)$ ve fen bilimlerinde $\left(-, 78298^{*}\right)$ faaliyet gösteren katılımcıların diğer alanlarda faaliyet gösteren katılımcılara göre daha az hayalperest olduğu sonucuna ulaşılmıştır. Akademik unvan açısından ise araştırma görevlilerinin (,44786*) profesörlere göre daha hayalperest olduğu görülmüştür. Yaş olarak da 25-34 yaş aralığındaki akademisyenlerin $35-44(29571 *)$ ve $45-54\left(, 37768^{*}\right)$ yaş aralığındakilere nazaran daha hayalperest olduğu tespit edilmiştir. Medeni durum açısından ise bekâr akademisyenlerin $\left(, 33981^{*}\right)$ evli akademisyenlere göre daha hayalperest olduğu sonucuna ulaşılmıştır. Öte yandan daha önce evlilik yaşamış ve ayrılmış olan akademisyenlerin $(x=2,1643)$ evlilere göre $(3,3273)$ hayalperestlik noktasında daha az bir ortalamaya sahip olması da bir diğer dikkat çeken bulgudur.

TSKÖ bağlamında çalışma alanı açısından katılımcıların siyasal tartışma $(\mathrm{F}=2,610)$ ve politika/hizmet takibi $(\mathrm{F}=4,342)$ boyutlarında anlamlı olarak farklılaştığı tespit edilmiştir $(\mathrm{p}<.05)$. Siyasal tartışmalara katılım noktasında güzel sanatlar alanında faaliyet gösterenler $\left(, 78598^{*}\right)$ sağlık alanındakilere göre daha aktif iken, politika hizmet takibi konusunda ise sosyal 
$\left(, 88533^{*}\right)$ ve fen bilimleri $(, 78862 *)$ alanındakiler sağlık alanındakilere nazaran daha faaldir. Akademik unvan bağlamında ise katılımcılar siyasal ifade $(\mathrm{F}=5,293)$, siyasal tartışma $(\mathrm{F}=2,607)$ ve yerel yönetime katılım $(\mathrm{F}=4,157)$ alt boyutları arasında istatistiki yönden anlamlı olarak farklılaşmaktadır $(\mathrm{p}<0.05)$. Siyasal ifade hususunda araştırma görevlileri, profesör $(, 39849 *)$ ve doçentlere $\left(, 42123^{*}\right)$ göre daha yoğun katılım göstermekteyken siyasal tartışmalara katılma açısından ise doktor öğretim üyeleri $\left(, 36301^{*}\right)$ profesörlere göre daha aktiftir. Yerel yönetime katılım çerçevesinde ise araştırma görevlilerinin (,38170*) doçentlerden daha fazla eylem sergilediği görülmektedir. Yaşa göre de katılımcılar siyasal ifade ve yerel yönetime katılım boyutlarında farklılaşmaktadır $(\mathrm{p}<0.05)$. Siyasal ifadede bulunma açısından 24 ve altındaki yaşa sahip akademisyenler $\left(, 66300^{*}\right) 55$ ve üzeri yaşa sahip akademisyenlere göre, 25-34 aralığındakiler $35-44\left(, 20493^{*}\right), 45-54(, 30349 *), 55$ ve üzeri $\left(, 50495^{*}\right)$ yaşındakilere göre daha yoğun çaba sarf etmektedir. Benzer şekilde yerel yönetime katılma konusunda da 24 ve altındaki yaşa sahip katılımcılar $(\overline{\mathrm{x}}=1,8000)$ en yüksek ortalamaya sahip gruptur. Medeni durum açısından ise siyasal ifade $(\mathrm{F}=4,062)$ ve yerel yönetime katılım $(\mathrm{F}=3,812)$ boyutlarında bir farklılaşma söz konusudur $(\mathrm{p}<0.05)$. Bekarlar, evlilere göre $\left(, 18107^{*}\right)$ siyasal ifadede bulunma noktasında ve yerel yönetime katılma hususunda $\left(, 19515^{*}\right)$ daha aktif rol almaktadırlar.

\section{Tartışma ve Sonuç}

E-katılım ve benlik saygısı arasındaki ilişkinin konu edindiği bu araştırmada entelektüel açıdan toplumun üst bir zümresini temsil eden akademisyenler üzerine Twitter platformu çerçevesinde bir araştırma gerçekleştirilmiştir. Kavramsal arka planda bahsedildiği üzere alan yazında ki genel kanaat; eğitim seviyesinin yükselmesi ile bireylerin BS düzeylerinin (Özkan, 1994, s. 6-7; Çetinkaya vd., 2006, s.119; Baybek ve Yavuz, 2005, s. 93-94; Özgüngör ve Paksu, 2017, s. 118119) ve siyasal katılım davranışlarının (Almond ve Verba, 1963, s. 265; Achen, 1975, s. 1218; Sabucedo ve Arce, 1991, s. 93; Eroğul, 1991, s. 108; Galston, 2004, s. 264) artacağını öngörmektedir. Araştırma kapsamında ulaşılan sonuçlara göre de akademisyenlerin benlik saygılarının yüksek olduğu tespit edilmiştir. Dolayısıyla bu bulgu literatürü desteklemektedir.

Öte yandan alan yazının aksine eğitim seviyesi açısından yüksek bir konumda bulunan akademisyenlerin siyasal katılım düzeylerinin oldukça düşük olduğu sonucuna ulaşılmıştır. Dolayısıyla geleneksel katılım biçimlerinde sıkça tartışılan katılım faaliyetlerine olan düşük ilgi (Eroğul, 1991; Çukurçayır, 2006; Dalton, 2008), akademisyenler açısından Twitter bazlı ekatılım faaliyetlerini de kapsamaktadır. Elbette bu durum ilgili platformun sosyal bir mecra olması açısından da tartışmaya açıktır. Diğer yandan katılımcıların \%87,5'inin kendilik kavramı açısından süreklilik arz eden bir yapıya sahip olduğunu da göz önünde bulundurmak gerekmektedir. Yukarıdaki bölümlerde bahsedildiği üzere, kendilik kavramı sürekliliği, bireylerin uzun bir süre zarfinda kendileri ile tutarlı davranışlar sergilemesini ifade etmektedir. Dolayısıyla katılımcıların \%87,5'i kendisini, benliği ile tutarlı ve uzun vadede değişmez bir yapıya sahip olarak tanımlamıştır. Bu durumda akademisyenlerin kendilik kavramları ile siyasal katılım durumları arasında gerçekleşen negatif yöndeki ilişki, akademisyenlerin geçmişten beri uzun bir süre boyunca siyasal katılıma dair (Twitter'da) pasif davranışlar sergileme eğilimi gösterdiklerini işaret etmektedir.

Katılımcıların genel itibariyle e-katılım düzeylerinin düşük bir seviyede olduğu, yalnızca platform üzerinden politika ve hizmet takibi konusunda ortalamanın üzerinde bir değere $(\mathrm{x}=3.06)$ sahip oldukları tespit edilmiştir. $\mathrm{Bu}$ veriden hareketle akademisyenlerin Twitter 
üzerinden gerçekleştirdiği e-katılım faaliyetleri izleyici/seyirci kategorisinde değerlendirilebilir. Wilcox ve Stephen'ın (2013) belirttiği üzere bireyler sosyal medya üzerinde güçlü ve yakın bağlantılarını dikkate alarak paylaşım gerçekleştirmektedirler. Bu noktada söz konusu katılım faaliyetlerinin siyasal bir tema üzerine gerçekleştiriyor olmasından ötürü akademisyenler, meslek ve statüleri gereği çekimser davranmış olabilir. Diğer bir bakış açısıyla Effing, Hillegersberg ve Huibers (2011) ise sosyal mecraların beklenilen aksine siyasal katılım noktasında önemli bir etkisi olmadığını dile getirmektedir. Bu bağlamda akademisyenlerin siyasal katılıma dair mevcut çekimser tutumlarının teknolojinin gelişimiyle sosyal mecralara yansıdı̆̆ da ihtimaller dâhilindedir.

Araştırmanın temel problemine dair RSBÖ dâhilinde TSKÖ ile aralarında pozitif yönde anlamlı ilişkinin tespit edildiği ilk değişkenin "hayalperestlik" alt boyutu olması da çalışma açısından dikkat çeken bir diğer sonuçtur. Nitekim literatürde politika ve hayal gücü ile ilgili araştırmalar irdelendiğinde Bernal'ın (2006) yeni medya, diaspora ve politik hayal gücü üzerine yapılandırdığı araştırma dikkat çekmektedir. Bernal'ın (2006) ilgili çalışmada ifade ettiği üzere bireyler yeni medya ortamlarında bir araya gelerek ortak amaçlar doğrultusunda yöneticilerin kararlarını inandıkları hayaller bağlamında etkileyebilmektedirler (s.162). Dolayısıyla hayalperestlik, siyasal katılım açısından önem arz eden bir bağlamdır. Evans (2015) bu noktada \#BlackLivesMatter gibi toplumsal hareketlerin arkasında yatan dijital hayal gücüne dikkat çekmektedir. Bu çalışma kapsamında da genel olarak siyasal katılım puanı düşük seyreden akademisyenlerin hayalperest olma durumlarının artmasıyla siyasal katılım davranışlarının artacağı sonucuna ulaşılmıştır. Öte yandan araştırma görevlilerinin profesörlere göre, daha genç akademisyenlerin yaşlı akademisyenlere göre, bekâr akademisyenlerin evli akademisyenlere göre daha hayalperest olduğu sonucunu hatırlatmak da yerinde olacaktır. Bu bağlamda hayalperestlik ve siyasal katılım ilişkisi bir değerlendirmeye tabi tutulduğunda dolaylı olarak hayalperestlik seviyesi yüksek seyreden genç ve bekâr akademisyenlerin Twitter'da e-katılım noktasında yaşlı ve evli katılımcılara göre daha aktif davranışlar sergilediği yorumunda bulunulabilir. Öte yandan tartışmalara katılabilme değişkeni ile de siyasal katılım değişkenleri arasında pozitif yönde düşük seviyede anlamlı bir ilişki olduğu sonucuna ulaşılmıştır. Benlik saygısı ve kendilik kavramı sürekliliği alt boyutları ise siyasal ifade, siyasal tartışmalara katılma ve yerel yönetime katılım boyutları ile negatif yönde düşük düzeyde anlamlı ilişki arz etmektedir.

Araştırma nihayetinde edinilen veriler 1şığında sonraki çalışmalar için aşağıdaki hususlar önerilmektedir;

$\mathrm{Bu}$ çalışma kapsamında edinilen bulgulara göre eğitim seviyesi yüksek katılımcılardan oluşan akademisyenlerin, Twitter çerçevesindeki e-katılım davranışlarının düşük düzeyde olduğu tespit edilmiştir. Öte yandan literatürdeki genel kanaat eğitim seviyesi yüksek bireylerin siyasal katılım faaliyetlerinin de yüksek seviyelerde olacağı şeklindedir. Dolayısıyla eğitim faktörünü de içine alan e-katılım temalı çalışmaların gerçekleştirilmesi ilgili alan yazına katkı sağlayacaktır. Bu çalışmalar sosyal medya platformları özelinde gerçekleştirilebileceği gibi dijital platformların geneli esas alınarak da gerçekleştirilebilir.

Öte yandan evli akademisyenlerin e-katılım davranışlarının düşük olmasının ardında yatan nedenler çeşitli değişkenler bağlamında (güvende hissetme içgüdüsü, sorumluluk) araştırılabilir. Bir diğer konu ise sağlık bilimleri alanında faaliyet gösteren akademisyenlerin e-katılım 
noktasında, diğer disiplin alanlarında faaliyet gösteren katılımcılara göre daha pasif davranışlar sergilemesidir. Bu kapsamda sağlık alanında çalışma yürüten akademisyenler üzerine siyasal katılım çerçevesinde araştırmalar gerçekleştirilebilir. Öte yandan kendilik kavramının sürekliliğini merkeze alan siyasal katılım temalı araştırmaların da alan yazına katkı sağlayacağı düşünülmektedir. Nitekim siyasal katılıma yönelik kararlar demokrasinin özü gereği değişebilen bir yapıya sahiptir. Öte yandan bireylerin kendileri ile tutarlı davranışlar sergilemesini konu edinen kendilik kavramının ilgili tutum üzerine belirleyiciliği merak uyandırmaktadır.

Benlik Saygısı ve E-Katılım İlişkisi: Twitter Ekseninde Akademisyenlere Yönelik Bir Uygulama başlıklı çalışmanın yazım sürecinde bilimsel, etik ve alıntı kurallarına uyulmuş; toplanan veriler üzerinde herhangi bir tahrifat yapılmamış, karşılaşılacak tüm etik ihlallerde "Pamukkale Üniversitesi Eğitim Fakültesi Dergisi Yayın Kurulunun" hiçbir sorumluluğunun olmadığı, tüm sorumluluğun Sorumlu Yazara ait olduğu ve bu çalışmanın herhangi başka bir akademik yayın ortamına değerlendirme için gönderilmemiş olduğunu taahhüt ederim. 


\section{Kaynakça}

Achen, C. (1975). Mass political attitudes and survey response. The American Political Science Review, 69(4), 1218-1231.

Almond, G. (1974). Comparative politics today: a world view. Boston: Little, Brawn and Company.

Aydın, B. (2005). Çocuk ve ergen psikolojisi. İstanbul: Atlas Yayınları.

Bakırcığlu, R. (2012). Ansiklopedik eğitim ve psikoloji sözcüğ̈̈. Ankara: Anı Yayınc1lık.

Barker, V. (2009). Older adolescents' motivations for social network site use: the influence of gender, group identity, and collective self-esteem. Cyberpsychology \& Behavior, 12(2), 209-213.

Baybek, H. ve Yavuz, S. (2005). Muğla üniversitesi öğrencilerinin benlik saygılarının incelenmesi. SBE Dergisi, 14, 73-95.

Bernal, V. (2006). Diaspora, cyberspace and political imagination: The Eritrean diaspora online. Global networks, 6(2), 161-179.

Boyd, D. M., N. B. Ellison (2008). Social network sites: definition, history, and scholarship. Journal of Computer-Mediated Communication, 13 (1), 210-30.

Brady, H. (1999). Political participation. In J. P. Robinson, P.R. Shaver, L. S. Wrightsman (Eds.). Measures of political attitudes, (pp. 737-801). San Diego: Academic Press.

Brewer, G., \& Kerslake, J. (2015). Cyberbullying, self-esteem, empathy and loneliness. Computers in Human Behavior, 48, 255-260.

Büyüköztürk, Ş. (2012). Örnekleme yöntemleri. [http://w3.balikesir.edu.tr/ msackes/wp/wpcontent/uploads/2012/03/BAY-Final-Konulari.pdf), Erişim Tarihi: 03.01.2019.

Can, G. (1990). Lise Öğrencilerinin Benlik Tasarımlarını Etkileyen Etmenler. Eskişehir: Anadolu Üniversitesi Basımevi.

Conge, P. J. (1988). The concept of political participation: toward a definition. Comparative Politics, 20(2), 241-249.

Çetinkaya, S., Arslan, S., Nur, N., Özdemir, D., Demir, Ö.F. ve Sümer, H. (2006). Sivas il merkezinde sosyoekonomik düzeyi farklı üç ilköğretim okulu öğrencilerinin benlik saygısı düzeyi. Klinik Psikiyatri Dergisi, 9(3): 116-122.

Çuhadaroğlu, F. (1986). Adolesanlarda benlik saygısı. Yayınlanmamış doktora tezi, Hacettepe Üniversitesi, Ankara.

Çukurçayır, M.A. (2006). Siyasal katılma ve yerel demokrasi. Konya: Çizgi Kitabevi.

Dalton, R. J. (2008). Citizenship norms and the expansion of political participation. Political studies, $56(1), 76-98$

Dilber, F. (2011). Siyasal katılımda kitle iletiş̧im araçlarının seçmenler üzerine etkisi; karaman ili seçmenleri üzerine bir alan araştırması. Yayınlanmamış doktora tezi, Selçuk Üniversitesi, Konya.

Doğan, T. ve Totan, T. (2009). Üniversite öğrencilerinde benlik saygısı ve sosyal zekâ. Sakarya Üniversitesi Ë̆itim Fakültesi Dergisi, 17, 235-247.

Donnellan, M. B., Trzesniewski, K. H., Robins, R. W., Moffitt, T. E., \& Caspi, A. (2005). Low selfesteem is related to aggression, antisocial behavior, and delinquency. Psychological Science, 16(4), 328-335. 
Effing, R., Van Hillegersberg, J., \& Huibers, T. (2011, August). Social media and political participation: are Facebook, Twitter and YouTube democratizing our political systems? In International conference on electronic participation (pp. 25-35). Springer, Berlin, Heidelberg.

Ekman, J., \& Amnå, E. (2012). Political participation and civic engagement: towards a new typology. Human affairs, 22(3), 283-300.

Eltantawy, N., \& Wiest, J. B. (2011). The arab spring| social media in the egyptian revolution: reconsidering resource mobilization theory. International journal of communication, 5, 18.

Erikson, E. (1993). Childhood and society. New York: W. W. Norton \& Company, Inc.

Eroğul, C. (1991). Devlet yönetimine kattlma hakkl. Ankara: İmge Kitabevi.

Evans, C. (2015). The nuts and bolts of digital civic imagination. DML Central.

Fromm, E. (1955). Sane society. New York: A Fawcett Premier Book.

Galston, W. A. (2004). Civic education and political participation. PS: Political Science \& Politics, 37(2), 263-266.

Güney, S. (2009). Davranış bilimleri. (5. Baskı). Ankara: Nobel Yayıncılık.

Harter, S. (1993). Causes and Consequences of Low Self-Esteem in Children and Adolescents. In Roy F. Baumeister (Ed.), Self-esteem (pp. 87-116). Boston: Springer.

Hermida, A. (2010). Twittering the news the emergence of ambient journalism. Journalism Practice, 4(3), 297-308.

HowTwitterWasBorn, (2018a). https://www.makeuseof.com/tag/how-twitter-was-born-geek-historylessons/. (Erişim Tarihi: 02.10.2018).

James, W. (1983). The principles of psychology. Cambridge: Harvard University Press.

Kalaycıŏ̆lu, E. (1983). Karşılaştırmalı siyasal katılma: siyasal eylemin kökenleri üzerine bir inceleme. İstanbul: İstanbul Üniversitesi Siyasal Bilimler Fakültesi Yayınları.

Kapani, M. (2009). Politika bilimine giriş. Ankara: Bilgi Yayınevi.

Karagöz, K. (2013). Yeni medya çağında dönüşen toplumsal hareketler ve dijital aktivizm hareketleri. Iletişim ve Diplomasi, 1(1), 131-156.

Karasar, N. (1984). Bilimsel araştırma yöntemi. Ankara: Hacettepe Taş Kitapçıllk.

Karkın, N. (2012). E-katılım kavramı ve süreci: kamu siyasa oluşum sürecine vatandaş katkısının olabilirliği. Sosyoekonomi, 8(17), s. 41-62.

Kaya, A., ve Saçkes, M. (2004). Benlik saygısı geliştirme programının ilköğretim 8. sınıf öğrencilerinin benlik saygısı düzeylerine etkisi. Türk Psikolojik Danışma ve Rehberlik Dergisi, 21, 49-56.

Kışlalı, A. T. (2006). Siyasal sistemler: siyasal çatışma ve uzlaşma. İmge Kitabevi.

Kim, C. L. (1974). Siyasal katılma ve uyarılmış oylama. İstanbul Üniversitesi İktisat Fakültesi Mecmuasl, 34(1-4), 89-121.

Korkmaz, G. (2005). Siyasal katılma ve üniversite gençliği-bilkent, başkent, ankara ve gazi üniversiteleri örnekleri. Yayınlanmamış doktora tezi. Hacettepe Üniversitesi, Ankara.

Kshetri, N., \& Voas, J. (2018). Blockchain-enabled e-voting. IEEE Software, 35(4), 95-99.

Li, Y., \& Marsh, D. (2008). New forms of political participation: Searching for expert citizens and everyday makers. British journal of political science, 38(2), 247-272. 
Macintosh, A. (2004). Characterizing e-participation in policy-making. Proceedings of the 37th Annual Hawaii International Conference on (pp. 10-pp). IEEE.

Marchlewska, M., Castellanos, K. A., Lewczuk, K., Kofta, M., \& Cichocka, A. (2019). My way or the highway: high narcissism and low self-esteem predict decreased support for democracy. British Journal of Social Psychology, 58(3), 591-608.

Meriç, Ö. (2013). Yeni medya ve dijital demokrasi: kuramsal tartısmalar. I. Uluslararast Siyasal İletişim Demokrasi ve Yeni Süreçler Kongresi. (s. 97-112).

Meriç, Ö. (2014). Dijital demokrasi: türkiye'de yeni medya ve siyasal katılım. Yayınlanmamaıs doktora tezi, Maltepe Üniversitesi, İstanbul.

Milbrath, Lester W. and Madan Lal Goel (1977) Political participation. how and why people get involved in politics. Chicago: RandMcNally.

Mruk, C. J. (2006). Self-Esteem research, theory, and practice: toward a positive psychology of selfesteem. New York: Springer Publishing Company.

Newman, T. P. (2017). Tracking the release of ipcc ar5 on twitter: users, comments, and sources following the release of the working group i summary for policymakers. Public Understanding of Science, 26(7), 815-825.

Özgüngör, S. ve Paksu, A. D. (2018). Üniversite öğrencilerinde benlik saygısı düzeyine göre akademik başarıyı yordayan değişkenler. Türk Psikolojik Danışma ve Rehberlik Dergisi, 7(48), 111-125.

Özkan, İ. (1994). Benlik saygısını etkileyen etkenler. Düşünen Adam, (7)3, 4- 9.

Parry, G., Moyser, G., Day, N. (1992). Political participation and democracy in britain. Cambridge: Cambridge University Press.

Rosenberg, M. (1965). Society and the adolescent self-image. NJ: Princeton University Press.

Sabucedo, J. M., \& Arce, C. (1991). Types of political participation: a multidimensional analysis. European Journal of Political Research, 20(1), 93-102.

Sæbø, Ø., Rose, J., \& Flak, L. S. (2008). The shape of eParticipation: characterizing an emerging research area. Government information quarterly, 25(3), 400-428.

Sagolla, D. (2009). 140 Characters a style guide for the short form. New Jersey: John Wiley \& Sons, Inc.

Schmitt, D. P., \& Allik, J. (2005). simultaneous administration of the rosenberg self-esteem scale in 53 nations: exploring the universal and culture-specific features of global self-esteem. Journal of Personality And Social Psychology, 89(4), 623.

Tatl1, E. (2012). Benlik saygısı ve şüphe durumları yönünden gençlerin siyasal reklamlara yaklaşımı Yayınlanmamış doktora tezi. Marmara Üniversitesi, İstanbul.

Tdk, (2018a). http://www.tdk.gov.tr/index.php?option=com_gts\&arama=gts\&kelime=benlik. Erişim tarihi: 01.08.2018.

Tdk, (2019a). http://sozluk.gov.tr/. Erişim tarihi: 10.07.2019.

TwitterAbout, (2018a). https://about.twitter.com/content/about-twitter/tr/values.html. Erişim Tarihi: 7.10.2018.

Uysal, B. (1984). Siyasal katılma ve katılma davranışına ailenin etkisi. Ankara: Türkiye ve Ortadoğu Amme İdaresi Enstitüsü Yayınları. 
Valkenburg, P. M., Peter, J., \& Schouten, A. P. (2006). Friend Networking sites and their relationship to adolescents' well-being and social self-esteem. CyberPsychology \& Behavior, 9(5), 584-590.

Van Deth, J. W. (2001, April). Studying political participation: Towards a theory of everything. In joint sessions of workshops of the European consortium for political research, Grenoble (pp. 6-11).

Verba, Sidney and Norman Nie (1972), Participation in america: political democracy and social equality. New York: Harper \& Row.

Webrazzi, (2018a). https://webrazzi.com/2014/04/04/elektronik-secim-turkiye/. Erişim tarihi: 31.10.2018.

Wilcox, K. ve Stephen, A.T. (2013). Article navigation are close friends the enemy? online social networks, self-esteem, and self-control. Journal of Consumer Research, 40(1), 90-103.

Yalçın, Ş. (2011). Ben neyim? An International Journal of Philosophy, 1, 29-38. 


\section{Extended Abstract}

\section{Introduction}

Human beings have an idea about objects and phenomena in the external world by developing certain attitudes and convictions against them. These convictions acquired by people may sometimes include positive judgments and negative judgments. At this point, the individual's attitudes towards his / her self are called self-esteem. It is seen that there are a very limited number of self-esteem studies on academicians. Therefore, in this research, the relationship between the self-esteem of academics and the political participation behaviors that they performed on the Twitter platform were discussed. It is stated in the literature that the education factor is an effective variable on political participation\& self-esteem and political participation $\&$ self-esteem will increase as the level of education increases. At this point, it is also a matter of interest for the research whether the participation and self-esteem of academicians representing a class having a high level of education will be as high as predicted in the literature or not.

\section{Method}

The study is based on a relational survey model. Relational survey models are research models dealing with the simultaneous change of two or more variables (Karasar, 1984, s. 82-85; Punch, 2013, s. 216). The target population of the research (Karasar, 1984, s. 115-116) was carried out by academicians from Uşak University, Gümüşhane University, and Süleyman Demirel University. The sample of the study consists of 503 academicians selected by stratified sampling (according to gender and status).

Three separate data collection tools were used in the study, which consisted of a total of 86 questions, Rosenberg's Self-Esteem Scale (RSES), Political Participation Scale In Twitter (PPST) and Personal Information Form (PIF).

RSES was developed by Morris Rosenberg in 1963, and reliability and validity studies in Turkey were carried out by Füsun Çuhadaroğlu in 1986 on 205 high school students (Cronbach's .71 - Test-Retest .79). The reliability coefficient (Cronbach's Alpha) in this study was calculated as .70. PPST was developed in a 5-point Likert style to measure the political participation behaviors on Twitter. It has five sub-dimensions: political expression, policy pursuit, participation/assistance to local government, propaganda march/strike and participation in political debates. In this study, the reliability coefficient for the whole scale was calculated as $\alpha=.94$. On the other hand, questions related to the field of study, title, age, gender and marital status of the participants are included in the PIF.

\section{Data Analysis}

The data obtained were analyzed with the SPSS 24.0 package program and evaluated.

\section{Results and Discussion}

$49.5 \%$ of the academicians participating in the research were female and $50.5 \%$ were male. $87.9 \%$ of the participants had high self-esteem and $12.1 \%$ had moderate self-esteem. The fact that no academician is included in the low self-esteem category is a remarkable outcome in terms of research. According to the findings of the research, the self-esteem of academicians 
and their political participation status on Twitter, there is a negative correlation between "political expression", "participation in political discussions" and "participation in local government". On the other hand, it has been concluded that the participation of the academicians in political expression, their "participation in political discussions" and their "participation in the local government" have increased with the increase in their dreamer side. According to the findings, another dimension of the RSES, which positively correlates with the PPST, is the variable named "participation in discussions". In this context, it was determined that the participation level of political participation on Twitter increased positively as their score to participate in the discussions increased. It was found that the political participation activities of the academicians in the Twitter platform were very low and that they were hesitant to express their opinions on political issues. However, it was found that their "self-esteem", "self-concept continuity" and "happiness in terms of depressive affect dimension" were quite high. According to the title, self-esteem levels of professors (,41888*), associate professors $\left(, 33209^{*}\right)$ and doctor faculty members $\left(21330^{*}\right)$ are higher than self-esteem levels of research assistants. Considering the differentiation values of self-esteem levels in terms of research assistants and other superior faculty members, it is observed that the difference coefficient increases gradually according to the hierarchy. Therefore, based on these data, it can be interpreted that the selfesteem level of academicians increases in each superior title. Self-esteem of academicians aged 24 and under is positioned at a lower level than academicians older than them. The level of selfesteem shows statistically significant difference according to the variable of "marital status". Married academics are positioned at a higher level $\left(, 13999^{*}\right)$ in terms of self-esteem than single academicians. It has been seen that the participants who had experienced marriage before do not have any difference in terms of self-esteem level compared to married or single academicians. In this context, the research findings support the thesis that self-esteem will increase with the increase in the education level in the literature and research findings contradict the opinion claiming that political participation will increase with the increase of the education level. 